\title{
Assisted Reproductive Technology Surveillance - United States, 2017
}

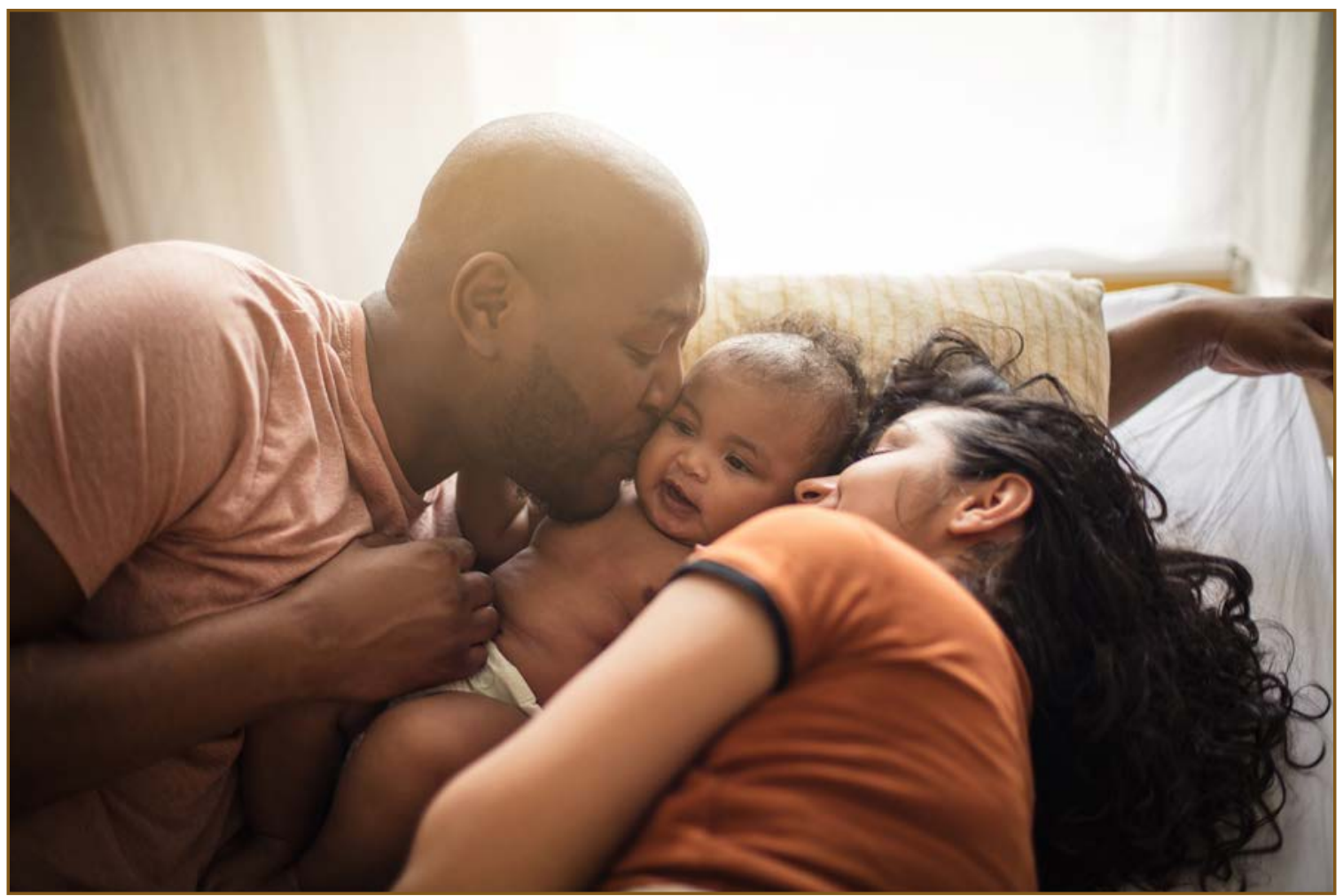




\section{CONTENTS}

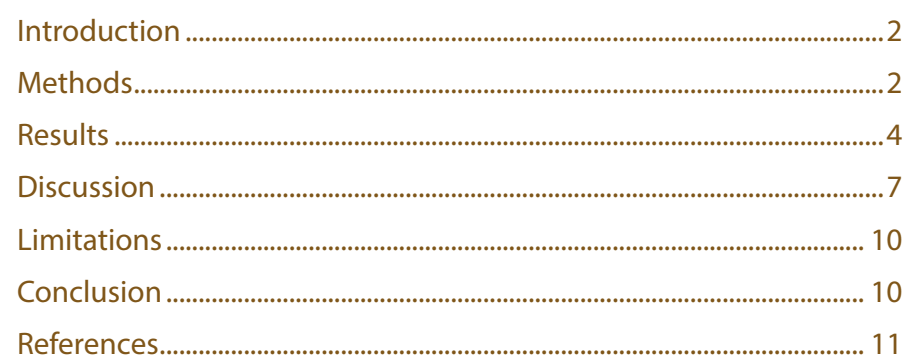

The MMWR series of publications is published by the Center for Surveillance, Epidemiology, and Laboratory Services, Centers for Disease Control and Prevention (CDC), U.S. Department of Health and Human Services, Atlanta, GA 30329-4027.

Suggested citation: [Author names; first three, then et al., if more than six.] [Title]. MMWR Surveill Summ 2020;69(No. SS-\#):[inclusive page numbers].

\section{Centers for Disease Control and Prevention Robert R. Redfield, MD, Director \\ Anne Schuchat, MD, Principal Deputy Director}

Chesley L. Richards, MD, MPH, Deputy Director for Public Health Science and Surveillance

Rebecca Bunnell, PhD, MEd, Director, Office of Science

Jennifer Layden, MD, PhD, Deputy Director, Office of Science

Michael F. Iademarco, MD, MPH, Director, Center for Surveillance, Epidemiology, and Laboratory Services

Charlotte K. Kent, PhD, MPH, Editor in Chief Christine G. Casey, MD, Editor

Mary Dott, MD, MPH, Online Editor

Terisa F. Rutledge, Managing Editor

David C. Johnson, Lead Technical Writer-Editor

Catherine B. Lansdowne, MS, Project Editor

Matthew L. Boulton, MD, MPH Carolyn Brooks, ScD, MA Jay C. Butler, MD Virginia A. Caine, MD

Jonathan E. Fielding, MD, MPH, MBA David W. Fleming, MD

\section{MMWR Editorial and Production Staff (Serials)}

Martha F. Boyd, Lead Visual Information Specialist Alexander J. Gottardy, Maureen A. Leahy,

Julia C. Martinroe, Stephen R. Spriggs, Tong Yang, Visual Information Specialists

Quang M. Doan, MBA, Phyllis H. King, Terraye M. Starr, Moua Yang,

Information Technology Specialists

MMWR Editorial Board

Timothy F. Jones, MD, Chairman

Kate Galatas, MPH

William E. Halperin, MD, DrPH, MPH

Jewel Mullen, MD, MPH, MPA

Jeff Niederdeppe, $\mathrm{PhD}$

Celeste Philip, MD, MPH

Patricia Quinlisk, MD, MPH
Ian Branam, MA, Acting Lead Health Communication Specialist Shelton Bartley, MPH,

Lowery Johnson, Amanda Ray, Jacqueline N. Sanchez, MS, Health Communication Specialists Will Yang, MA,

Visual Information Specialist

Patrick L. Remington, MD, MPH Carlos Roig, MS, MA William Schaffner, MD Nathaniel Smith, MD, MPH

Morgan Bobb Swanson, BS 


\title{
Assisted Reproductive Technology Surveillance - United States, 2017
}

\author{
Saswati Sunderam, $\mathrm{PhD}^{1}$; Dmitry M. Kissin, $\mathrm{MD}^{1}$; Yujia Zhang, $\mathrm{PhD}^{1}$; Amy Jewett, $\mathrm{MPH}^{1}$; Sheree L. Boulet, DrPH${ }^{2}$; Lee Warner, $\mathrm{PhD}^{1}$; \\ Charlan D. Kroelinger, $\mathrm{PhD}^{1}$; Wanda D. Barfield, $\mathrm{MD}^{1}$ \\ ${ }^{1}$ Division of Reproductive Health, National Center for Chronic Disease Prevention and Health Promotion, CDC; \\ ${ }^{2}$ Emory University, School of Medicine, Atlanta, Georgia
}

\begin{abstract}
Problem/Condition: Since the first U.S. infant conceived with assisted reproductive technology (ART) was born in 1981, both the use of ART and the number of fertility clinics providing ART services have increased steadily in the United States. ART includes fertility treatments in which eggs or embryos are handled in the laboratory (i.e., in vitro fertilization [IVF] and related procedures). Although the majority of infants conceived through ART are singletons, women who undergo ART procedures are more likely than women who conceive naturally to have multiple-birth infants because multiple embryos may be transferred. Multiple births can pose substantial risks for both mothers and infants, including obstetric complications, preterm birth $(<37$ weeks), and low birthweight $(<2,500 \mathrm{~g})$. This report provides state-specific information for the United States (including the District of Columbia and Puerto Rico) on ART procedures performed in 2017 and compares birth outcomes that occurred in 2017 (resulting from ART procedures performed in 2016 and 2017) with outcomes for all infants born in the United States in 2017.
\end{abstract}

Period Covered: 2017.

Description of System: In 1995, CDC began collecting data on ART procedures performed in fertility clinics in the United States as mandated by the Fertility Clinic Success Rate and Certification Act of 1992 (Public Law 102-493 [October 24, 1992]). Data are collected through the National ART Surveillance System (NASS), a web-based data collection system developed by CDC. This report includes data from the 50 states, the District of Columbia, and Puerto Rico.

Results: In 2017, a total of 196,454 ART procedures (range: 162 in Alaska to 24,179 in California) with at least one embryo transferred were performed in 448 U.S. fertility clinics and reported to CDC. These procedures resulted in 68,908 live-birth deliveries (range: 67 in Puerto Rico to 8,852 in California) and 78,052 infants born (range: 85 in Puerto Rico to 9,926 in California). Nationally, the number of ART procedures performed per 1 million women of reproductive age (15-44 years) was 3,040. ART use rates exceeded the national rate in 14 states (Connecticut, Delaware, District of Columbia, Hawaii, Illinois, Maryland, Massachusetts, New Hampshire, New Jersey, New York, Rhode Island, Utah, Vermont, and Virginia). ART use exceeded 1.5 times the national rate in seven states (Connecticut, the District of Columbia, Illinois, Maryland, Massachusetts, New Jersey, and New York).

Nationally, among all ART transfer procedures, the average number of embryos transferred increased slightly with increasing age (1.3 among women aged <35 years, 1.4 among women aged 35-37 years, and 1.5 among women aged $>37$ years). This year, single-embryo transfer (SET) rates among all embryo-transfer procedures are presented instead of elective single-embryo transfer procedures previously reported. Nationally, SET rates were 67.3\% (range: 38.9\% in South Dakota to 90.4\% in Delaware), 65.0\% (range: $23.6 \%$ in Puerto Rico to $89.4 \%$ in Delaware), and 60.0\% (range: 28.6\% in Puerto Rico to $83.1 \%$ in Delaware) among women aged $<35$ years, aged $35-37$ years, and aged $>37$ years, respectively.

In 2017, ART contributed to $1.9 \%$ of all infants born in the United States (range: $0.4 \%$ in Puerto Rico to 5.0\% in Massachusetts). Approximately $73.6 \%$ of ART-conceived infants were singleton infants. Overall, ART contributed to $14.7 \%$ of all multiple births, including $14.7 \%$ of all twin infants and $17.3 \%$ of all triplets and higher-order infants. ART-conceived twins accounted for approximately $96.5 \%(18,890$ of 19,570) of all ART-conceived infants born in multiple deliveries. The percentage of multiple births was higher among infants conceived with ART (26.4\%) than among all infants born in the total birth population (3.4\%). Approximately $25.5 \%$ of ART-conceived infants were twins, and

Corresponding author: Saswati Sunderam, Division of Reproductive Health, National Center for Chronic Disease Prevention and Health Promotion, CDC. Telephone: 770-488-6356; E-mail: msunderam@cdc.gov. $0.9 \%$ were triplets and higher-order infants.

Nationally, infants conceived with ART contributed to $4.5 \%$ of all low birthweight $(<2,500 \mathrm{~g})$ infants. Among ART-conceived infants, $20.2 \%$ had low birthweight, compared with $8.3 \%$ among 
all infants. ART-conceived infants contributed to $5.3 \%$ of all preterm (gestational age $<37$ weeks) infants. The percentage of preterm births was higher among infants conceived with ART (27.8\%) than among all infants born in the total birth population (9.9\%).

The percentage of low birthweight among singletons was $8.1 \%$ among ART-conceived infants and $6.6 \%$ among all infants born. The percentage of preterm births among ART-conceived singleton infants was $14.0 \%$, compared with $8.1 \%$ among all singleton infants. The percentages of small for gestational age infants was $7.6 \%$ among ART-conceived infants, compared with $9.9 \%$ among all infants.

Interpretation: Although singleton infants accounted for the majority of ART-conceived infants, multiple births from ART still contributed to a substantial proportion of all twins, triplets, and higher-order infants born in the United States. Variations in SET rates among states and territories were noted, reflecting variations in embryo-transfer practices among fertility clinics, which might in part account for higher multiple birth from ART observed in some states and territories.

Public Health Action: Reducing the number of embryos transferred and increasing use of SET, when clinically appropriate, can help reduce multiple births and related adverse health consequences for both mothers and infants. Because infants from multiple births are at increased risk for numerous adverse sequelae that cannot be ascertained from the data collected through NASS alone, long-term follow-up for ART infants through integration of existing maternal and infant health surveillance systems and registries with data available from NASS might be useful for monitoring adverse outcomes on a population basis.

\section{Introduction}

Since the birth of the first U.S. infant conceived with assisted reproductive technology (ART) in 1981, use of advanced technologies to overcome infertility has increased, as has the number of fertility clinics providing ART services and procedures in the United States (1). In 1992, Congress passed the Fertility Clinic Success Rate and Certification Act of 1992 (Public Law 102-493 [October 24, 1992]), which requires that all U.S. fertility clinics performing ART procedures report data to CDC annually on every ART procedure performed. CDC initiated data collection in 1995 and in 1997 published the first annual ART Fertility Clinic Success Rates Report (2). The annual ART Fertility Clinic Success Rates Report presents multiple measures of success for ART, including the percentage of ART procedures and transfers that result in live-birth deliveries.

Although ART has helped millions of women achieve pregnancy, the treatment is associated with potential health risks for both mothers and infants. Because multiple embryos can be transferred in ART procedures, ART might result in multiple-gestation pregnancies and multiple births (3- ). Risks to the mother from a multiple-birth pregnancy include higher rates of caesarean delivery, maternal hemorrhage, pregnancyrelated hypertension, and gestational diabetes $(7-10)$. Risks to the infant include preterm birth, low birthweight, birth defects, developmental disability, and death (11-14). In addition, singleton infants conceived with ART might have higher risk for low birthweight and prematurity than singletons not conceived with ART $(15,16)$. However, recent research suggests that this higher risk might be associated with singleton births resulting from multiple-embryo transfers among patients who were not good candidates for single-embryo transfer (SET) (17).
This report was compiled from data provided and verified by ART clinics about ART procedures performed in 2017 and reported to CDC's Division of Reproductive Health. Data on the use of ART are presented for residents of each U.S. state, the District of Columbia, and Puerto Rico. Data also are reported on outcomes for infants born in 2017 resulting from ART procedures performed in 2016 and 2017. The report examines the proportion of ART among selected outcomes (e.g., multiple births, low birthweight infants, preterm infants, and small for gestational age [SGA] infants) and compares outcomes among ART-conceived infants with outcomes among all infants born in the United States in 2017.

\section{Methods}

\section{National ART Surveillance System}

In 1995, CDC initiated data collection of ART procedures performed in the United States. ART data are obtained from all fertility clinics in the United States that provided and verified information about the outcomes of the ART cycles through the National ART Surveillance System (NASS), a web-based data collection system developed by CDC (https://www.cdc.gov/ art/nass/index.html). Clinics that are members of the Society for Assisted Reproductive Technology (SART) can report their data to NASS through SART. Clinics that are not members of SART can enter their data directly into NASS. All clinics must verify the accuracy of the data they reported in the clinic table in the annual ART Fertility Clinic Success Rates Report before finalizing submission to NASS. The data then are compiled by a CDC contractor and reviewed for accuracy. In 2017, 10.0\% of clinics did not report their data to CDC and are listed as 
nonreporting clinics in the 2017 ART Fertility Clinic Success Rates Report, as required by the Fertility Clinic Success Rate and Certification Act of 1992. Because nonreporting clinics tend to be smaller on average than reporting clinics, NASS is estimated to contain information on $98 \%$ of all ART procedures in the United States (1).

Data collected include patient demographics, medical history, and infertility diagnoses; clinical information pertaining to the ART procedure type; and information regarding resultant pregnancies and births. The data file contains one record per ART procedure (i.e., cycle of treatment performed). Because ART providers typically do not provide continued prenatal care after a pregnancy is established, ART clinics collect information on live births for all procedures from patients and physicians.

\section{ART Procedures}

ART includes fertility treatments in which eggs or embryos are handled in a laboratory (i.e., in vitro fertilization [IVF], gamete intrafallopian transfer, and zygote intrafallopian transfer). More than $99 \%$ of ART procedures performed are IVF. Because an ART procedure consists of multiple steps over an interval of approximately 2 weeks, and sometimes longer because of preimplantation genetic testing performed to select euploid embryos or for disease screening, a procedure often is referred to as a cycle of treatment. An ART cycle usually begins with drug-induced ovarian stimulation. If eggs are produced, the cycle progresses to the egg-retrieval stage, which involves surgical removal of the eggs from the ovaries. After the eggs are retrieved, they are combined with sperm in a laboratory during the IVF procedure. For certain IVF procedures $(75.0 \%$ in 2017) (1), a specialized technique (intracytoplasmic sperm injection) is used in which a single sperm is injected directly into the egg. If successful fertilization occurs, the most viable embryos (i.e., those that appear morphologically most likely to develop and implant) are selected for transfer back into the uterus. If an embryo implants in the uterus, a clinical pregnancy is diagnosed by the presence of a gestational sac detectable by ultrasound. On average, less than half of the procedures result in a clinical pregnancy. Most pregnancies will progress to a livebirth delivery, defined as the delivery of one or more live-born infants; however, some result in pregnancy loss $(18,19)$. ART does not include treatments in which only sperm are handled (i.e., intrauterine insemination) or procedures in which a woman is administered drugs to stimulate egg production without the intention of having eggs retrieved.

ART procedures are classified on the basis of the source of the egg (patient or donor) and the status of the eggs and embryos. Both fresh and thawed embryos can be derived from fresh or frozen eggs of the patient or donor. Patient and donor embryos can be created using sperm from a partner or donor. ART procedures involving fresh eggs and embryos include an egg-retrieval stage. ART procedures that use thawed eggs or embryos do not include egg retrieval because the eggs were retrieved during a previous ART procedure, and either the eggs were frozen or fertilized and the resultant embryos were frozen until the current ART procedure. An ART cycle can be discontinued at any step for medical reasons or by patient choice.

\section{Birth Data for United States}

Data on the total numbers of live births, including singleton and multiple births, in each reporting area in 2017 were obtained from U.S. natality files $(20-22)$. The natality online databases report counts of live births occurring within the United States to residents and nonresidents. The data are derived from birth certificates.

\section{Variables and Definitions}

Data on ART procedures and birth outcomes are presented by patient's residence (i.e., state or territory) at the time of treatment, which might not be the same as the location where the procedure was performed. If information on a patient's residence was missing, residence was assigned as the location where the procedure was performed $(0.3 \%$ of procedures performed in 2017 and $0.1 \%$ of live-birth deliveries occurring in 2017). ART procedures performed in the United States among non-U.S. residents are included in NASS data. However, they are excluded from certain calculations; the appropriate denominators were not available because the women might have delivered outside the United States. To protect confidentiality, table cells with values of $1-4$ for ART-conceived infants and 0-9 for all infants are suppressed. The cell suppression criteria for the ART population allows for the representation of some clinics, which carry out only a small number of cycles, while maintaining minimum risks for identification. ART data from U.S. territories (with the exception of Puerto Rico) are not included in this report. In addition, percentages derived from cell values $<20$ in the denominator have been suppressed because they are unstable.

This report presents data on all procedures initiated with the intent to transfer at least one embryo, including procedures that used thawed embryos for transfer. All cycles in which egg or embryo banking was performed for future ART cycles were excluded. The number of ART procedures performed per 1 million women of reproductive age (15-44 years) was calculated. Data regarding population size were compiled on the basis of July 1, 2017, estimates from the U.S. Census Bureau (23). The resulting rate approximates the proportion 
of women of reproductive age who used ART in each state or territory. This proxy measure of ART use is only an approximation because certain women who use ART fall outside the age range of $15-44$ years (approximately $6 \%$ of cycles performed in 2017), and certain women might have had more than one procedure during the reporting period.

A live-birth delivery was defined as a birth of one or more infants. A singleton live-birth delivery was defined as a delivery of only one infant who was born live. A multiple live-birth delivery was defined as a delivery of two or more infants, at least one of whom was born live. Low birthweight was defined as $<2,500 \mathrm{~g}$, moderately low birthweight as $1,500-2,499 \mathrm{~g}$, and very low birthweight as $<1,500 \mathrm{~g}$. Gestational age for births among women who did not undergo ART procedures was calculated using obstetric estimate of gestational age at delivery (24). For births to women who underwent fresh ART procedures, gestational age was calculated by subtracting the date of egg retrieval from the birth date and adding 14 days. For births to women who underwent frozen embryo cycles or fresh ART procedures for which the date of retrieval was not available, gestational age was calculated by subtracting the date of embryo transfer from the birth date and adding 17 days (to account for an average of 3 days in embryo culture). Preterm birth was defined as gestational age $<37$ weeks, late preterm $34-36$ weeks, early preterm $<34$ weeks, and very preterm $<32$ weeks (22).

New in 2017, SET procedures among all embryo-transfer procedures are reported instead of reporting elective SET (eSET) procedures only among patients who used fresh embryos from their own fresh eggs, as in previous reports. In an eSET procedure, only one embryo is selected for transfer from a larger number of available embryos, and the remaining embryos are cryopreserved. In comparison, SET is a procedure in which one embryo is selected for transfer, regardless of how many embryos were available. Therefore, the rate of SET is expected to be higher than the rate of eSET because SET procedures include both eSET procedures and procedures in which only one embryo is available for transfer. This transition from eSET to SET follows changes in clinical practice, such as increasing use of frozen embryos and expanded recommendations to transfer a single embryo regardless of how many embryos are cryopreserved due to increasing use of preimplantation genetic screening, which can facilitate the selection of euploid embryos $(5,25)$. This guidance adopted a broader approach and recommended single-embryo transfer for patients of any age transferring an euploid embryo, selected with the assistance of preimplantation genetic screening, and for patients aged $<38$ years with any one of these criteria: 1) availability of quality embryos for cryopreservation, 2) history of live birth after an IVF procedure, 3) availability of vitrified blastocyst stage embryos, or 4) undergoing first frozen-embryo transfer (5). The rate of SET was calculated by dividing the total number of SET procedures by the total number of embryo-transfer procedures performed and reported by the following age groups: $<35$ years, $35-37$ years, and $>37$ years. The average number of embryos transferred by age group ( $<35$ years, 35-37 years, and $>37$ years) was calculated by dividing the total number of embryos transferred by the total number of embryo-transfer procedures performed among that age group.

The proportion of ART infants among all births in a particular state or territory was used as a second measure of ART use. The proportion of adverse outcomes among ART-conceived infants (e.g., preterm birth) was calculated by dividing the total number of adverse outcomes among ARTconceived infants by the total number of adverse outcomes among all infants born.

The percentage of infants (ART conceived and all infants) born in a state or territory for each plurality group (singleton, multiple, twin, and triplet and higher-order birth) was calculated by dividing the number of infants (ART conceived and all infants) in each plurality group by the total number of infants born (ART conceived and all infants). The percentage of infants with low birthweight and preterm birth was calculated only for singleton births for ART-conceived infants and for all infants by dividing the number of low birthweight or preterm infants among singletons by the total number of singleton infants.

In addition, the percentage of singleton infants who were SGA (defined as $<10$ th percentile of birthweight for gestational age week and limited to 22-44 weeks) was calculated using a reference distribution (26). The percentage of singleton SGA infants was calculated for all births by dividing the number of singleton SGA infants in the gestational age category (week) by the total number of singleton infants in that gestational age category for ART-conceived and all infants, respectively.

To assess the proportion of ART births among U.S. births in 2017, ART births were aggregated from two reporting years: 1) infants conceived with ART procedures performed in 2016 and born in 2017 (71.5\% of the live-birth deliveries reported to NASS for 2017) and 2) infants conceived with ART procedures performed in 2017 and born in 2017 (28.5\% of the live-birth deliveries reported to NASS for 2017).

\section{Results}

\section{Overview of Fertility Clinics}

In 2017, a total of 498 fertility clinics in the United States performed ART procedures and $448(90.0 \%)$ provided data 
to CDC, with the majority located in or near major cities (1). The number of fertility clinics performing ART procedures varied by state or territory. The states with the largest numbers of fertility clinics providing data were California (68), Texas (41), and New York (40) (Figure 1).

\section{Number and Type of ART Procedures}

The number, type, and outcome of ART procedures performed are provided according to patient's residence for all 52 states and territories and non-U.S. residents (Table 1). Residency data were missing for approximately $0.3 \%$ of procedures performed, and in these cases, the patient's residence was assigned as the location where the ART procedure was performed. In 2017 , approximately $13.8 \%$ of ART procedures were performed in a state or territory other than the patient's state or territory of residence. Non-U.S. residents accounted for approximately $3.6 \%$ of ART procedures, $4.3 \%$ of ART live-birth deliveries, and $4.5 \%$ of ART-conceived infants born.

In 2017, a total of 284,403 ART procedures were reported to CDC (1). Included in this report are data for 196,454 ART procedures performed (range: 162 in Alaska to 24,179 in California) in the United States (including Puerto Rico) with the intent to transfer at least one embryo (Table 1) (Figure 2). Excluded are 87,931 cycles in which egg or embryo banking was performed and 18 research cycles in which a new treatment procedure was being evaluated. Of 196,454 procedures performed in the 52 states or territories, 157,499 (80.2\%) progressed to embryo transfer. Of 157,499 ART procedures that progressed to the embryo-transfer stage, 84,340 (53.5\%) resulted in a pregnancy and 68,908 (43.8\%) in a live-birth delivery (range: 67 in Puerto Rico to 8,852 in California). The 68,908 live-birth deliveries included 59,891 singleton deliveries (86.9\%) and 9,017 multiple deliveries (13.1\%) and resulted in 78,052 live-born infants (range: 85 in Puerto Rico to 9,926 in California).

Six states with the largest numbers of ART procedures (California, Illinois, Massachusetts, New Jersey, New York, and Texas) accounted for approximately half $(48.6 \%$; 95,522 of $196,454)$ of all ART procedures, $48.2 \%(75,866$ of 157,499$)$ of all embryo-transfer procedures, $46.3 \%(36,141$ of 78,052$)$ of all ART-conceived infants born, and $41.5 \%$ (3,742 of 9,017) of all ART-conceived multiple live-birth deliveries in the United States (Table 1). However, these six states accounted for only $36.2 \%$ of all U.S. births (22).

The number of ART procedures per 1 million women of reproductive age (15-44 years) ranged from 338 in Puerto Rico to 7,366 in Massachusetts, with an overall national rate of 3,040 (Table 1) (Figure 3). Fourteen states (Connecticut,
FIGURE 1. Location and number* of assisted reproductive technology clinics, by quartile — United States and Puerto Rico, 2017

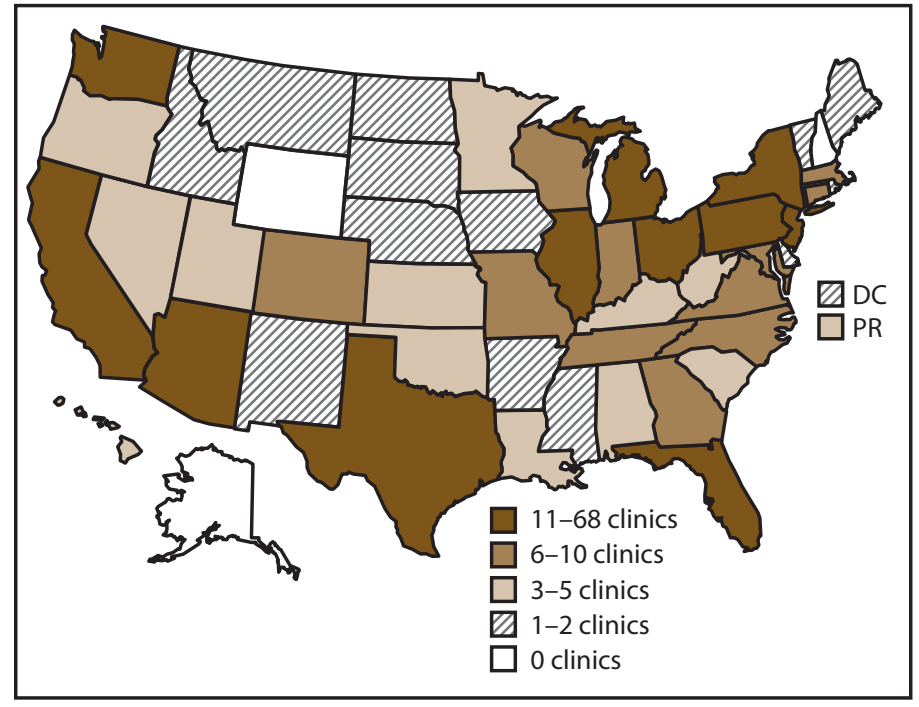

Abbreviations: $\mathrm{DC}=$ District of Columbia; $\mathrm{PR}=$ Puerto Rico.

* In 2017, of the 498 clinics in the United States, 448 (90\%) submitted data.

Delaware, District of Columbia, Hawaii, Illinois, Maryland, Massachusetts, New Hampshire, New Jersey, New York, Rhode Island, Utah, Vermont, and Virginia) had ART use rates higher than the national rate. Of these, the District of Columbia $(6,806)$, Massachusetts $(7,366)$, and New Jersey $(6,158)$ had rates exceeding twice the national rate, whereas Connecticut $(5,228)$, Illinois $(5,031)$, Maryland $(5,580)$, and New York $(5,816)$ had rates exceeding 1.5 times the national rate. The three areas with the lowest ART use rates were Puerto Rico (338), New Mexico (928), and Mississippi (979).

\section{Number of Embryos Transferred}

The number of embryo-transfer procedures performed, the average number of embryos transferred per procedure, and the percentage of SET procedures among all embryo-transfer procedures performed are provided by state or territory and age group (Table 2). Overall, 65,387 embryo-transfer procedures were performed among women aged $<35$ years, 35,789 among women aged 35-37 years, and 56,323 among women aged $>37$ years. Nationally, on average, 1.3 embryos were transferred per procedure among women aged $<35$ years, 1.4 embryos among women aged 35-37 years, and 1.5 embryos among women aged $>37$ years. The national SET rate was $67.3 \%$ among women aged $<35$ years (range: $38.9 \%$ in South Dakota to $90.4 \%$ in Delaware), $65.0 \%$ among women aged $35-37$ years (range: $23.6 \%$ in Puerto Rico to $89.4 \%$ in Delaware), and $60.0 \%$ among women aged $>37$ years (range: $28.6 \%$ in Puerto Rico to $83.1 \%$ in Delaware). 
FIGURE 2. Number of outcomes of assisted reproductive technology procedures* with the intent to transfer at least one embryo, by type of outcome - United States and Puerto Rico, 2017

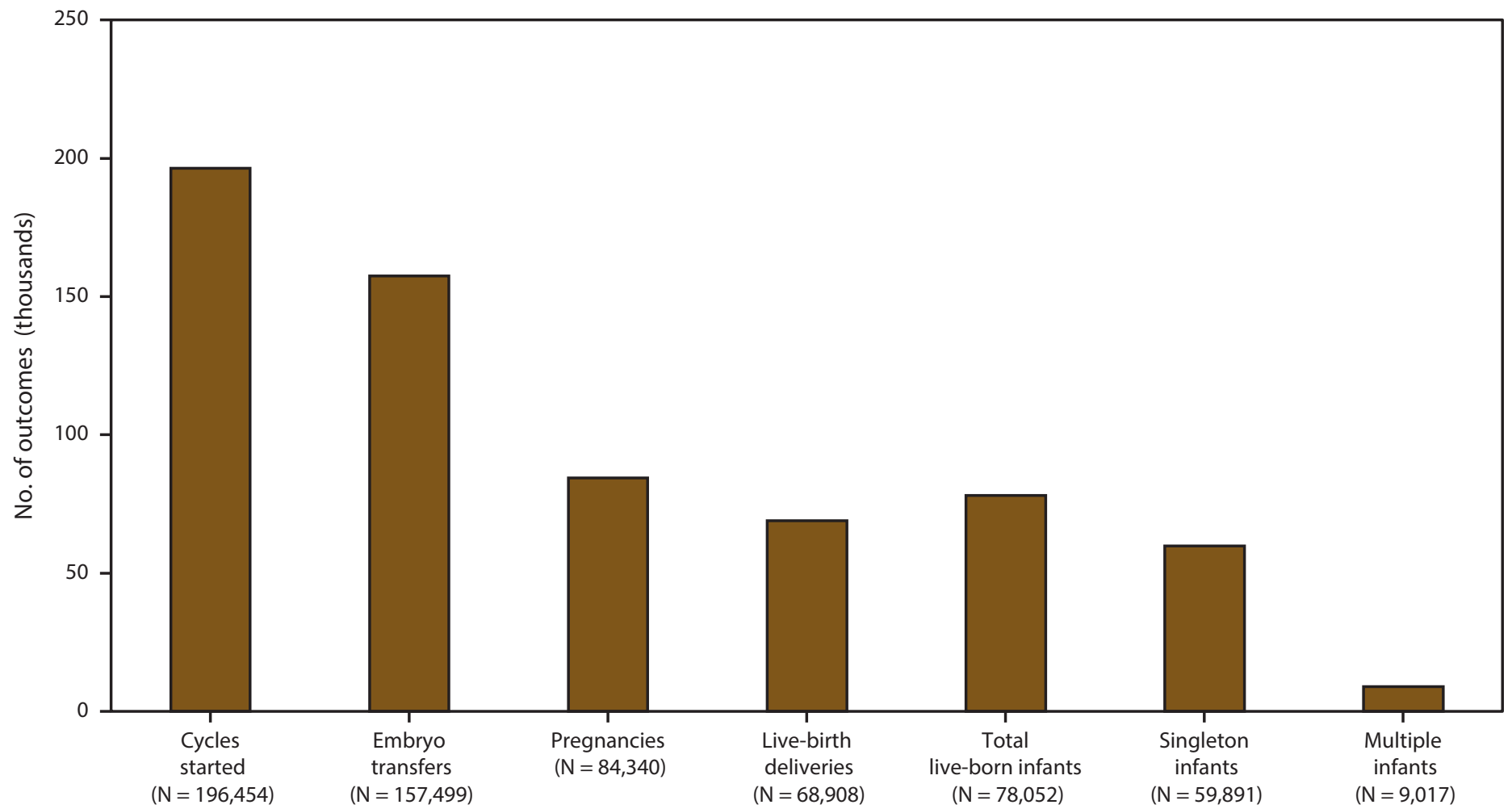

Type of outcome

* A total of 284,403 assisted reproductive technology procedures were reported to CDC. Excluded are 87,931 cycles in which egg or embryo banking was performed and 18 research cycles in which a new treatment procedure was being evaluated.

\section{Singleton and Multiple Births}

In 2017, among 3,879,810 infants born in the United States and Puerto Rico, 74,006 (1.9\%) were conceived with ART procedures performed in 2016 and 2017 (Table 3). California, Texas, and New York had the highest total numbers of all infants born (471,658; 382,050; and 229,737, respectively) and ART-conceived infants born $(9,844 ; 6,164$; and 7,495, respectively). The percentage of ART-conceived infants among all infants born was highest in Massachusetts (5.0\%), followed by the District of Columbia and Connecticut ( $4.4 \%$ and $4.3 \%$, respectively).

Nationally, $26.4 \%$ of ART-conceived infants were born in multiple-birth deliveries (range: $9.7 \%$ in Delaware to $45.5 \%$ in North Dakota and Puerto Rico), compared with 3.4\% of all infants (range: $2.0 \%$ in Puerto Rico to $4.1 \%$ in Connecticut) (Table 4). ART-conceived twins accounted for approximately $96.5 \%(18,890$ of 19,570$)$ of all ART-conceived infants born in multiple-birth deliveries. ART-conceived multiple-birth infants contributed to $14.7 \%$ of all multiple births (range: $5.4 \%$ in Mississippi to $31.7 \%$ in Hawaii). Approximately $25.5 \%$ of all ART-conceived infants were twins, compared with 3.3\% of all infants. ART-conceived twins contributed to $14.7 \%$ of all twins. Of ART-conceived infants, $0.9 \%$ were triplets and higher-order multiples, compared with $0.1 \%$ among all infants. ART-conceived triplets and higher-order infants contributed to $17.3 \%$ of all triplets and higher-order infants.

\section{Adverse Perinatal Outcomes}

Nationally, ART-conceived infants contributed to $4.5 \%$ of all infants with low birthweight, $4.5 \%$ of all infants with moderately low birthweight, and $4.6 \%$ of all infants with very low birthweight (Table 5). Among all ART-conceived infants (including multiples), $20.2 \%$ had low birthweight, compared with $8.3 \%$ among all infants (including multiples). Approximately $3.5 \%$ of all ART-conceived infants (including multiples) had very low birthweight, compared with $1.4 \%$ among all infants (including multiples).

Nationally, ART contributed to approximately $5.3 \%$ of all infants born very preterm, $6.0 \%$ early preterm, $5.1 \%$ late preterm, and $5.3 \%$ preterm (Table 6). In Connecticut, Massachusetts, and New Jersey, the contribution of ART to preterm infants exceeded $10 \%$ in all categories of preterm birth. 
FIGURE 3. Number of reporting states and territories, ${ }^{*}$ by number of assisted reproductive technology procedures performed ${ }^{\dagger}$ among women of reproductive age (15-44 years) ${ }^{\S}$ in which at least one embryo was transferred — United States and Puerto Rico, 2017

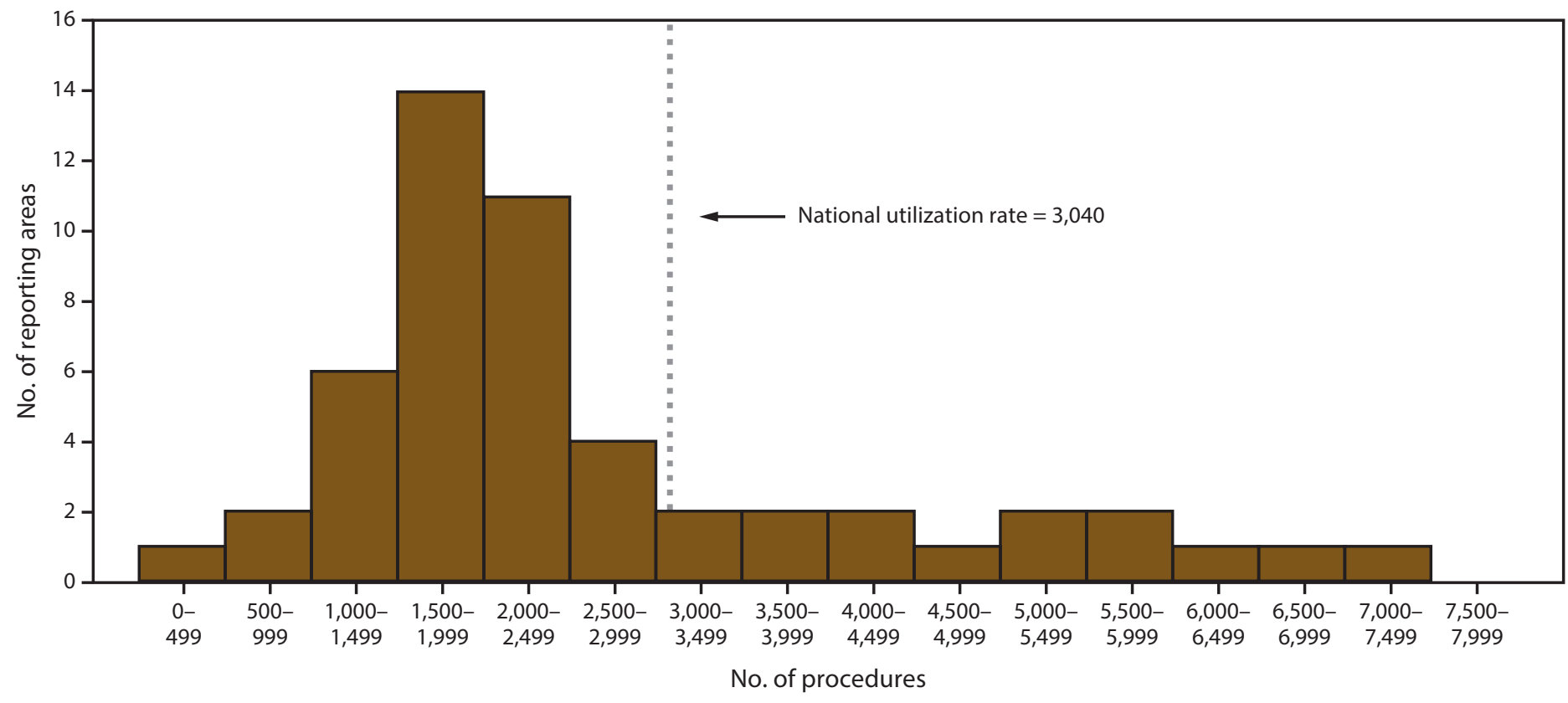

* Total number of reporting states and territories: 52 .

† Total number of procedures: 196,454 .

$\S$ Per 1 million women aged $15-44$ years.

" National utilization rate $=$ (Total number of procedures performed $/$ Female population aged 15-44 years) $\mathrm{X}$ 1,000,000.

Among all ART-conceived infants (including multiples), rates for preterm birth were $4.5 \%$ very preterm, $8.7 \%$ early preterm, $19.2 \%$ late preterm, and $27.8 \%$ preterm. Corresponding rates of preterm birth among all infants (including multiples) born were $1.6 \%$ very preterm, $2.8 \%$ early preterm, $7.2 \%$ late preterm, and $9.9 \%$ preterm. Late preterm births accounted for the majority of preterm births both among ART-conceived infants and all infants $(69.0 \%$ and $72.0 \%$, respectively).

Among singletons only, the percentage of infants who had low birthweight was $8.1 \%$ among ART-conceived infants and $6.6 \%$ among all infants. In addition, among singletons, the percentage of infants who were born preterm was $14.0 \%$ among ART-conceived infants and $8.1 \%$ among all infants, and the percentage of SGA infants was $7.6 \%$ among ARTconceived infants and $9.9 \%$ for infants with gestational age of 22-44 weeks (Table 7).

\section{Discussion}

\section{Overview}

The use of ART has increased substantially in the United States since the beginning of ART surveillance. In 1996 (the first full year for which ART data were reported to CDC), 20,597 infants were born from 64,036 ART procedures performed by 302 reporting clinics. Since then, the number of procedures reported and the number of infants born from ART procedures have more than tripled, and the number of clinics performing ART services has also increased substantially. Multiple improvements can be observed in ART outcomes by comparing years 2016 (27) and 2017. The percentage of singleton births increased from $68.5 \%$ to $73.6 \%$ (a $7.4 \%$ increase), and the percentage of twin births decreased from $30.4 \%$ to $25.5 \%$ (a $16.1 \%$ decrease). The percentage of triplets and higher-order births decreased from $1.1 \%$ to $0.9 \%$. The percentage of low birthweight among ARTconceived infants decreased from $23.6 \%$ to $20.2 \%$, and preterm birth rates among ART-conceived infants decreased from $29.9 \%$ to $27.8 \%$. The contribution of ART-conceived twins to all twins born in the United States decreased from $16.2 \%$ to $14.7 \%$. The contribution of ART-conceived infants to all triplets and higherorder infants decreased from $19.4 \%$ to $17.3 \%$.

Despite these declines, ART disproportionally contributes to multiple births and poor birth outcomes (low birthweight and preterm birth). In 2017, the multiple-birth rate was nearly eight times higher among ART-conceived infants compared with all infants $(26.4 \%$ versus $3.4 \%)$. Although infants conceived with ART accounted for approximately $1.9 \%$ of total births in the United States, the proportion of multiple births attributable to ART was $14.7 \%$. The percentage of infants with low birthweight or born preterm was 2.4 and 
2.8 times higher among ART-conceived infants $(20.2 \%$ and $27.8 \%$, respectively) than among all infants ( $8.3 \%$ and $9.9 \%$, respectively). Nationally, even among singletons, the rate of preterm birth among ART-conceived infants was two times the preterm birth rate among all infants. Because ART infants are more likely to be multiple births than infants among the general population, their contribution to adverse outcomes such as preterm birth continues to be noteworthy.

\section{Variations in ART Use by Reporting Area}

The rate of ART use, as measured by number of procedures performed per 1 million women of reproductive age, declined slightly from 3,075 to 3,040 between reporting years 2016 and 2017. ART use varied across areas. Residents of 14 states (Connecticut, Delaware, District of Columbia, Hawaii, Illinois, Maryland, Massachusetts, New Hampshire, New Jersey, New York, Rhode Island, Utah, Vermont, and Virginia) had higher rates of ART use than the national rate.

Residents of California, Illinois, Massachusetts, New Jersey, New York, and Texas accounted for almost half (48.2\%) of all infants conceived with ART. The large number of ART procedures performed in these six states is a result of both the size of the general population (e.g., California and Texas) and high rates of ART use per capita (e.g., Massachusetts, Illinois, New Jersey, and New York).

The contribution of ART to all infants born varied substantially by state. State-level differences might be explained in part by variations in health insurance coverage and disparities in access to fertility services. Seventeen states (Arkansas, California, Connecticut, Delaware, Hawaii, Illinois, Louisiana, Maryland, Massachusetts, Montana, New Hampshire, New Jersey, New York, Ohio, Rhode Island, Texas, and West Virginia) have laws mandating that private insurers provide coverage for some fertility treatments, although not all mandates require coverage for $\operatorname{ART}(28,29)$. Eleven states (Arkansas, Connecticut, Delaware, Hawaii, Illinois, Maryland, Massachusetts, New Hampshire, New Jersey, New York, and Rhode Island) have insurance mandates that cover at least one ART cycle. Six states (California, Louisiana, Montana, Ohio, Texas, and West Virginia) have insurance mandates that exclude IVF coverage. Mandates from four states (Illinois, Massachusetts, New Jersey, and Rhode Island) include comprehensive coverage for at least four oocyte retrievals. In addition, Connecticut also covers up to two IVF cycles, with a maximum of two embryos transferred. Three of the four states with comprehensive mandates (Illinois, Massachusetts, and New Jersey) had rates of ART use that were at least $50 \%$ higher than the national rate. Insurance mandates for infertility treatments have been associated with greater use of
ART (30-32). Other possible contributors to differences in ART use across states might include factors affecting access to fertility services, such as infertility diagnosis, evaluation, and treatment (33).

Race and ethnicity might be associated with use of fertility services. One study that analyzed 2014 NASS data showed that ART use was highest among Asians/Pacific Islanders, followed by White non-Hispanic women, whereas non-Hispanic Black, Hispanic, and American Indian/Alaska Native non-Hispanic women had less than the national average levels of use (33). Because many insurance plans in the United States do not cover ART treatment, costs are often the responsibility of individual patients (30). Even in states with an insurance mandate, ART use rates among women aged $15-44$ years for non-Hispanic Black and Hispanic women were lower than the overall national use rate (33). A study that linked NASS data to state vital registries data in Florida, Massachusetts, and Michigan also found disparities by maternal race and ethnicity in ART use. However, limitations of data collection systems in terms of data quality and completeness of race and ethnicity data may limit meaningful research in racial and ethnic disparities in ART use and outcomes (33). As of 2016, all states had adopted the 2003 revision of the birth certificate that includes information on whether the pregnancy resulted from the use of infertility treatment; 47 states and the District of Columbia differentiate between the use of ART and non-ART treatments. Improved data collection and data linkages to obtain accurate data on race and ethnicity would facilitate research in this area. In 2014, CDC's National Public Health Action Plan for the Detection, Prevention, and Management of Infertility identified racial disparities in the prevalence, diagnosis, referral, and treatment of infertility as a public health priority and called for improved monitoring of infertility treatment services to reduce disparities in infertility treatments and outcomes (34).

\section{Single-Embryo Transfer Rates}

Recommendations issued by the American Society for Reproductive Medicine and SART to limit the number of embryos transferred have been revised multiple times to reduce higher-order multiple deliveries (25,35-37). However, the most recent guidance in 2017 also was aimed at reducing all multiple births, including twins (5). Because of the change in clinical practice, in 2017, NASS surveillance began reporting SET rates among all embryo transfers instead of eSET for patients using fresh embryos from their own fresh eggs, which is different from previous reports $(1,25)$. Although this transition allows a more accurate representation of current embryotransfer practices, it limits the assessment of changes in these practices over time using data from previous reports. Similar 
to variations by state in eSET, variations in the percentage of SET procedures across states and territories suggest that SET might not be implemented equally in all areas.

\section{ART Multiple Births}

Singleton births have lower risks than multiple births for adverse birth outcomes, such as prematurity, low birthweight, developmental disability, and death $(13,38,39)$. To optimize healthy birth outcomes, the transfer of fewer embryos should be encouraged when clinically appropriate, taking into consideration the patient's age and prognosis $(5,40)$. The percentage of multiple births among ART-conceived infants in the United States decreased from 53.1\% in 2000 (when national multiple birth rates were first reported in the Surveillance Summary) to $26.4 \%$ in 2017 (41). A substantial decrease was noted for both the percentage of ART-conceived triplets and higher-order infants (from $8.9 \%$ in 2000 to $0.9 \%$ in 2017) and the percentage of ART-conceived twins (from $44.2 \%$ in 2000 to $25.5 \%$ in 2017). States with the highest SET rates (i.e., Delaware, the District of Columbia, and Massachusetts) also had the lowest rates of ART-conceived multiple births.

Transferring two embryos is associated with a slight increase in the overall birth rate but a greater increase in the twin birth rate compared with transferring a single embryo $(42,43)$. However, transferring two embryos sequentially (singleembryo transfer over two sequential procedures, if the first procedure did not result in live birth) has similar cumulative live-birth rates and substantially lower twin delivery rates than transferring two embryos in a single procedure and might be a cost-effective approach, in which estimated costs include ART treatment and pregnancy-and infant-associated medical costs $(42,43)$. Evidence from other countries suggests that access to coverage for ART, availability of cryopreservation services, and economic and social factors regarding the number of embryos transferred per cycle can encourage SET procedures and reduce multiple births (44). In 2013, the mean health care costs to patients and insurers were estimated at $\$ 26,922$ for ARTconceived singleton deliveries, $\$ 115,238$ for ART-conceived twin deliveries, and $\$ 434,668$ for ART-conceived triplets and higher-order infants (45).

The desire for twins among couples experiencing infertility and their perception that the benefits of a multiple-gestation pregnancy (compared with no pregnancy) outweigh the risks (46-48) might partially explain why twin rates remain high. Therefore, understanding the perspective of couples undergoing infertility treatments regarding multiple-gestation pregnancies and multiple births is important. Patient education focusing on maternal and perinatal morbidity and mortality and the economic costs of twin gestations has been effective in reducing the preference for twins among patients undergoing ART (49-51).

\section{ART Low Birthweight Infants, Preterm Births, and Small for Gestational Age Infants}

In the United States, although rates of ART-conceived preterm and low birthweight infants have been declining steadily, the percentage of infants born with low birthweight and preterm was higher among ART-conceived infants $(20.2 \%$ and $27.8 \%$, respectively) than among all infants $(8.3 \%$ and 9.9\%, respectively). In addition, among ART-conceived infants, preterm and low birthweight rates varied substantially across states and territories. For example, the percentage of ART-conceived infants born in gestational weeks 34-36 varied from $11.6 \%$ (in the District of Columbia) to $32.2 \%$ (in Puerto Rico), whereas less variation by state was observed for same gestational week (34-36 weeks) category among all infants (range: $5.6 \%$ in Vermont to $9.7 \%$ in Mississippi).

Fertility treatments, both ART and non-ART, contribute substantially to preterm births $(38,52)$. Preterm births are a leading cause of infant morbidity and mortality, and preterm infants are at higher risk for health and developmental problems and death than full-term infants (38,53-55). The health risks associated with preterm birth have contributed to increased health care costs. In 2016, the societal economic cost associated with all preterm births in the United States was estimated at $\$ 25.2$ billion annually ( $\$ 64,815$ per infant born preterm) based on updates to estimates originally reported by a 2007 Institute of Medicine report (38) (https://www.marchofdimes. org/peristats/documents/Cost_of_Prematurity_2019.pdf). The societal economic cost associated with ART-conceived preterm infants in the United States in 2017 was also re-estimated at approximately $\$ 1.3$ billion on the basis of estimates computed in 2012 (56). Furthermore, the economic costs of multiple births underscore the importance of efforts to reduce ART-related multiple births, which in turn would reduce preterm births.

In addition to the known risks for multiple births associated with ART, singleton infants conceived with ART procedures are at increased risk for preterm birth (14.0\%) compared with all singleton infants $(8.1 \%)$. Among singletons, SGA rates were lower among ART-conceived infants compared with all infants. Other studies have shown variability in SGA risk by fresh versus frozen and donor versus autologous cycles $(57,58)$. Although low birthweight is a risk factor for adverse effects among newborns and is usually associated with preterm births, SGA might be a better indicator of these risk factors among 
newborns because it accounts for gestational age (57). More research is needed to better understand the risk for SGA among ART-conceived infants and how risk for SGA might vary by the type of ART cycle performed.

Use of ART only partially explains the overall prevalence of adverse outcomes such as multiple births in the United States. Other factors influencing multiple births include advanced maternal age at conception and the use of non-ART fertility treatments $(38,52,59,60)$. During 1980-2009, a substantial increase in the number of twin infants occurred due to the older age of women giving birth (59). The risk for multiple gestations associated with non-ART fertility treatments (i.e., controlled ovarian stimulation and ovulation induction coupled with timed intercourse or intrauterine insemination) is less well-documented than that associated with ART procedures; fertility clinics are only required to report data on ART use to NASS. However, research suggests that nonART fertility treatments contribute to a larger percentage of multiple births than ART. In 2015, approximately 17\% of multiple births in the United States were attributable to IVF fertility treatments, whereas $29 \%$ were attributable to non-IVF fertility treatments $(61,62)$.

Additional efforts are needed to monitor the use of non-ART fertility treatments and their role in multiple births, particularly because the ability to control the occurrence of a multiple birth is more challenging when using non-ART fertility treatments (52). CDC is monitoring the prevalence of ART and nonART fertility treatment use and resultant outcomes among women who had live births in certain states participating in the Pregnancy Risk Assessment Monitoring System $(63,64)$.

\section{Limitations}

The findings in this report are subject to several limitations. First, ART surveillance data were reported for each ART procedure performed rather than for each patient who used ART. As a result, because patients can undergo multiple procedures, measures of ART use are an approximation; certain women who use ART are younger or older than the age range of 15-44 years, and certain women might have had more than one procedure during the reporting period. Therefore, the procedure-specific use rates reported here might be higher than the actual per-patient use rates. Second, when comparisons are made between ART-conceived births and all births, all births include the ART-related births. Similarly, when comparing outcomes for ART-conceived infants versus all infants, the denominator for all infants born includes ART-conceived infants. Third, preterm birth, low birthweight, and being small for gestational age could be associated with factors contributing to underlying infertility or other maternal or paternal factors and not necessarily ART procedures. Fourth, approximately $10 \%$ of fertility clinics that performed ART in 2017 did not report their data to CDC. Although these clinics might have had results differing from reporting clinics, typically, they are smaller and represent approximately $2 \%$ of all ART cycles performed in the United States (1). Fifth, SET rates cannot be compared with eSET rates from previous years because of differences in definition between eSET and SET rates. In addition, in previous reports, eSET rates were reported only for procedures in which patients were using their own fresh eggs. SET rates were calculated for all procedures except procedures in which banking was performed for future ART use (and therefore no eggs or embryos were retrieved) and procedures that were considered research cycles. Sixth, comparisons between ART births and all U.S. births should be limited because some ART calculations might exclude births to nonU.S. residents because the data are reported by mother's state of residence. However, the NVSS data that are derived from the birth certificates include all births, including births to nonU.S. residents. Seventh, gestational age is computed for ART infants conceived with frozen embryos by subtracting 17 days (to allow for an average of 3 days in embryo culture) from the date of transfer. However, many frozen-embryo transfers use blastocyst embryos (approximately 5 days of embryo culture), which might slightly underestimate gestational age. Finally, the number of ART procedures reported for 2017 included all procedures in which banking was not performed, including procedures with frozen eggs that were thawed, and therefore comparisons with data from previous years (2015 and earlier) in which procedures using thawed eggs were excluded from analyses should be made with caution.

\section{Conclusion}

Since 1995, the number of ART procedures performed in the United States and the number of infants born as a result of ART procedures have more than tripled. With this increasing use, ART-conceived infants represented approximately $2 \%$ of infants born in the United States in 2017 and contributed substantially to the prevalence of low birthweight and preterm births. Furthermore, among ART-conceived infants, although the percentage of all multiple births has decreased since 2000, the percentage of twins, which has also declined, still remains high (26\%). Because of higher rates of preterm birth among multiple births, ART has a disproportionate number of poor birth outcomes. This report provides information that allows state health departments working with patients and clinical organizations to monitor the extent of ART-related adverse 
perinatal outcomes in their regions and take action to initiate programs and policies to reduce the adverse effects of ART multiple births. A state-specific website that presents selected ART success rates and other statistics is available (https://www. cdc.gov/art/state-specific-surveillance/index.html).

\section{Conflicts of Interest}

All authors have completed and submitted the International Committee of Medical Journal Editors form for disclosure of potential conflicts of interest. No potential conflicts of interest were disclosed.

\section{References}

1. CDC. 2017 Assisted reproductive technology success rates. Atlanta, GA: US Department of Health and Human Services. 2019.

2. CDC. 1995 Assisted reproductive technology success rates. Atlanta, GA: US Department of Health and Human Services; 1997.

3. Schieve LA, Peterson HB, Meikle SF, et al. Live-birth rates and multiplebirth risk using in vitro fertilization. JAMA 1999;282:1832-8. PMID:10573274 https://doi.org/10.1001/jama.282.19.1832

4. Reynolds MA, Schieve LA, Martin JA, Jeng G, Macaluso M. Trends in multiple births conceived using assisted reproductive technology, United States, 1997-2000. Pediatrics 2003;111:1159-62. PMID: 12728130

5. Penzias A, Bendikson K, Butts S, et al; Practice Committee of the American Society for Reproductive Medicine; Practice Committee of the Society for Assisted Reproductive Technology. Guidance on the limits to the number of embryos to transfer: a committee opinion. Fertil Steril 2017;107:901-3. PMID:28292618 https://doi.org/10.1016/j. fertnstert.2017.02.107

6. The ESHRE Capri Workshop Group. Multiple gestation pregnancy. Hum Reprod 2000;15:1856-64. PMID:10920117 https://doi. org/10.1093/humrep/15.8.1856

7. Di Tommaso M, Sisti G, Colombi I, et al. Influence of assisted reproductive technologies on maternal and neonatal outcomes in early preterm deliveries. J Gynecol Obstet Hum Reprod 2019;48:845-8. PMID:30898633 https://doi.org/10.1016/j.jogoh.2019.03.008

8. Le Ray C, Pelage L, Seco A, et al; Epimoms Study Group. Risk of severe maternal morbidity associated with in vitro fertilisation: a populationbased study. BJOG 2019;126:1033-41. PMID:30801948 https://doi. org/10.1111/1471-0528.15668

9. Santana DS, Surita FG, Cecatti JG. Multiple pregnancy: epidemiology and association with maternal and perinatal morbidity. Rev Bras Ginecol Obstet 2018;40:554-62. PMID:30231294 https://doi. org/10.1055/s-0038-1668117

10. MacKay AP, Berg CJ, King JC, Duran C, Chang J. Pregnancy-related mortality among women with multifetal pregnancies. Obstet Gynecol 2006;107:563-8. PMID:16507925 https://doi.org/10.1097/01. AOG.0000200045.91015.c6

11. Fountain C, Zhang Y, Kissin DM, et al. Association between assisted reproductive technology conception and autism in California, 19972007. Am J Public Health 2015;105:963-71. PMID:25790396 https:// doi.org/10.2105/AJPH.2014.302383

12. Boulet SL, Kirby RS, Reefhuis J, et al; States Monitoring Assisted Reproductive Technology (SMART) Collaborative. Assisted reproductive technology and birth defects among liveborn infants in Florida, Massachusetts, and Michigan, 2000-2010. JAMA Pediatr 2016;170:e154934. PMID:27043648 https://doi.org/10.1001/ jamapediatrics.2015.4934
13. Boulet SL, Schieve LA, Nannini A, et al. Perinatal outcomes of twin births conceived using assisted reproduction technology: a populationbased study. Hum Reprod 2008;23:1941-8. PMID:18487216 https:// doi.org/10.1093/humrep/den169

14. Dawson AL, Tinker SC, Jamieson DJ, et al; National Birth Defects Prevention Study. Twinning and major birth defects, National Birth Defects Prevention Study, 1997-2007. J Epidemiol Community Health 2016;70:1114-21. PMID:27325867 https://doi.org/10.1136/ jech-2015-206302

15. Pandey S, Shetty A, Hamilton M, Bhattacharya S, Maheshwari A. Obstetric and perinatal outcomes in singleton pregnancies resulting from IVF/ICSI: a systematic review and meta-analysis. Hum Reprod Update 2012;18:485-503. PMID:22611174 https://doi.org/10.1093/humupd/ $\mathrm{dms} 018$

16. Qin JB, Sheng XQ, Wu D, et al. Worldwide prevalence of adverse pregnancy outcomes among singleton pregnancies after in vitro fertilization/intracytoplasmic sperm injection: a systematic review and meta-analysis. Arch Gynecol Obstet 2017;295:285-301. PMID:27896474 https://doi.org/10.1007/s00404-016-4250-3

17. Martin AS, Chang J, Zhang Y, et al; States Monitoring Assisted Reproductive Technology (SMART) Collaborative. Perinatal outcomes among singletons after assisted reproductive technology with singleembryo or double-embryo transfer versus no assisted reproductive technology. Fertil Steril 2017;107:954-60. PMID:28292615 https:// doi.org/10.1016/j.fertnstert.2017.01.024

18. Farr SL, Schieve LA, Jamieson DJ. Pregnancy loss among pregnancies conceived through assisted reproductive technology, United States, 1999-2002. Am J Epidemiol 2007;165:1380-8. PMID:17351291 https://doi.org/10.1093/aje/kwm035

19. Hipp H, Crawford S, Kawwass JF, Chang J, Kissin DM, Jamieson DJ. First trimester pregnancy loss after fresh and frozen in vitro fertilization cycles. Fertil Steril 2016;105:722-8. PMID:26627121 https://doi. org/10.1016/j.fertnstert.2015.11.012

20. National Center for Health Statistics. Vital statistics data available. Natality public use file and CD-ROM. Hyattsville, MD: National Center for Health Statistics, CDC. https://www.cdc.gov/nchs/data_access/ vitalstatsonline.htm

21. CDC Wonder [Internet]. Natality public use data 2007-2018. US Department of Health and Human Services, CDC; 2018. https:// wonder.cdc.gov

22. Martin JA, Hamilton BE, Osterman MJK, Driscoll AK. Births: final data for 2018. Natl Vital Stat Rep 2019;68:1-47. PMID:32501202

23. US Census Bureau. Annual estimates of the resident population for selected age groups by sex for the United States, states, counties, and Puerto Rico Commonwealth and municipios: April 1, 2010 to July 1, 2018. Washington, DC: US Census Bureau, Population Division; 2018. https://data.census.gov/cedsci/table?q=United\%20States\&g=0100000 US\&tid=ACSST1Y2018.S0101\&vintage $=2018$

24. Martin JA, Osterman MJ, Kirmeyer SE, Gregory EC. Measuring gestational age in vital statistics data: Transitioning to the obstetric estimate. Natl Vital Stat Rep 2015;64:1-20. PMID:26047089

25. Practice Committee of the American Society for Reproductive Medicine; Practice Committee of the Society for Assisted Reproductive Technology. Criteria for number of embryos to transfer: a committee opinion. Fertil Steril 2013;99:44-6. PMID:23095140 https://doi.org/10.1016/j. fertnstert.2012.09.038

26. Talge NM, Mudd LM, Sikorskii A, Basso O. United States birth weight reference corrected for implausible gestational age estimates. Pediatrics 2014;133:844-53. PMID:24777216 https://doi.org/10.1542/ peds.2013-3285

27. Sunderam S, Kissin DM, Zhang Y, et al. Assisted reproductive technology surveillance-United States, 2016. MMWR Surveill Summ 2019;68(No. SS-4). PMID:31022165 https://doi.org/10.15585/mmwr. ss6804a 1 
28. Zagadailov P, Seifer DB, Shan H, Zarek SM, Hsu AL. Do state insurance mandates alter ICSI utilization? Reprod Biol Endocrinol 2020;18:33. PMID:32334609 https://doi.org/10.1186/s12958-020-00589-w

29. Resolve. Infertility coverage by state. McLean, VA: Resolve; 2020. https:// resolve.org/what-are-my-options/insurance-coverage/ infertility-coverage-state

30. Henne MB, Bundorf MK. Insurance mandates and trends in infertility treatments. Fertil Steril 2008;89:66-73. PMID:17482603 https://doi. org/10.1016/j.fertnstert.2007.01.167

31. Hamilton BH, McManus B. The effects of insurance mandates on choices and outcomes in infertility treatment markets. Health Econ 2012;21:994-1016. PMID:21905150 https://doi.org/10.1002/ hec. 1776

32. Boulet SL, Crawford S, Zhang Y, et al; States Monitoring ART Collaborative. Embryo transfer practices and perinatal outcomes by insurance mandate status. Fertil Steril 2015;104:403-9.e1. PMID:26051096 https://doi.org/10.1016/j.fertnstert.2015.05.015

33. Dieke AC, Zhang Y, Kissin DM, Barfield WD, Boulet SL. Disparities in assisted reproductive technology utilization by race and ethnicity, United States, 2014: a commentary. J Womens Health (Larchmt) 2017;26:605-8. PMID:28586255 https://doi.org/10.1089/ jwh.2017.6467

34. CDC. National public health action plan for the detection, prevention, and management of infertility. Atlanta, GA: CDC; 2014. https://www. cdc.gov/reproductivehealth/infertility/pdf/drh_nap_final_508.pdf

35. Practice Committee of Society for Assisted Reproductive Technology; Practice Committee of American Society for Reproductive Medicine. Guidelines on number of embryos transferred. Fertil Steril 2008;90(Suppl):S163-4. PMID:19007617 https://doi.org/10.1016/j. fertnstert.2008.08.053

36. Practice Committee of the American Society for Reproductive Medicine; Practice Committee of the Society for Assisted Reproductive Technology. Guidelines on number of embryos transferred. Fertil Steril 2009;92:1518-9. PMID:19836732 https://doi.org/10.1016/j. fertnstert.2009.08.059

37. Practice Committee of the Society for Assisted Reproductive Technology; Practice Committee of the American Society for Reproductive Medicine. Guidelines on number of embryos transferred. Fertil Steril 2006;86(Suppl 1):S51-2. PMID:17055845 https://doi.org/10.1016/j. fertnstert.2006.07.1473

38. Behrman RE, Butler AS, eds. Institute of Medicine (US) Committee on Understanding Premature Birth and Assuring Healthy Outcomes. Premature birth: causes, consequences, and prevention. Washington, DC: National Academies Press; 2007.

39. Practice Committee of American Society for Reproductive Medicine. Multiple gestation associated with infertility therapy: an American Society for Reproductive Medicine Practice Committee opinion. Fertil Steril 2012;97:825-34. PMID:22192352 https://doi.org/10.1016/j. fertnstert.2011.11.048

40. Kissin DM, Kulkarni AD, Kushnir VA, Jamieson DJ; National ART Surveillance System Group. Number of embryos transferred after in vitro fertilization and good perinatal outcome. Obstet Gynecol 2014;123:239-47. PMID:24402601 https://doi.org/10.1097/ AOG.0000000000000106

41. Wright VC, Schieve LA, Reynolds MA, Jeng G. Assisted reproductive technology surveillance-United States, 2000. MMWR Surveill Summ 2003;52(No. SS-9). PMID:14532867

42. Luke B, Brown MB, Wantman E, et al. Application of a validated prediction model for in vitro fertilization: comparison of live birth rates and multiple birth rates with 1 embryo transferred over 2 cycles vs 2 embryos in 1 cycle. Am J Obstet Gynecol 2015;212:676.e1-7. PMID:25683965 https://doi.org/10.1016/j.ajog.2015.02.005
43. Crawford S, Boulet SL, Mneimneh AS, et al. Costs of achieving live birth from assisted reproductive technology: a comparison of sequential single and double embryo transfer approaches. Fertil Steril 2016;105:444-50. PMID:26604068 https://doi.org/10.1016/j. fertnstert.2015.10.032

44. Maheshwari A, Griffiths S, Bhattacharya S. Global variations in the uptake of single embryo transfer. Hum Reprod Update 2011;17:107-20. PMID:20634207 https://doi.org/10.1093/humupd/dmq028

45. Lemos EV, Zhang D, Van Voorhis BJ, Hu XH. Healthcare expenses associated with multiple vs singleton pregnancies in the United States. Am J Obstet Gynecol 2013;209:586.e1-11. PMID:24238479 https:// doi.org/10.1016/j.ajog.2013.10.005

46. Grobman WA, Milad MP, Stout J, Klock SC. Patient perceptions of multiple gestations: an assessment of knowledge and risk aversion. Am J Obstet Gynecol 2001;185:920-4. PMID:11641679 https://doi. org/10.1067/mob.2001.117305

47. Blennborn M, Nilsson S, Hillervik C, Hellberg D. The couple's decisionmaking in IVF: one or two embryos at transfer? Hum Reprod 2005;20:1292-7. PMID:15734759 https://doi.org/10.1093/humrep/ deh785

48. Pinborg A, Loft A, Schmidt L, Andersen AN. Attitudes of IVF/ICSItwin mothers towards twins and single embryo transfer. Hum Reprod 2003;18:621-7. PMID:12615836 https://doi.org/10.1093/humrep/ $\operatorname{deg} 145$

49. Ryan GL, Sparks AE, Sipe CS, Syrop CH, Dokras A, Van Voorhis BJ. A mandatory single blastocyst transfer policy with educational campaign in a United States IVF program reduces multiple gestation rates without sacrificing pregnancy rates. Fertil Steril 2007;88:354-60. PMID:17490657 https://doi.org/10.1016/j.fertnstert.2007.03.001

50. Hope N, Rombauts L. Can an educational DVD improve the acceptability of elective single embryo transfer? A randomized controlled study. Fertil Steril 2010;94:489-95. PMID:19442970 https://doi. org/10.1016/j.fertnstert.2009.03.080

51. Sunderam S, Boulet SL, Jamieson DJ, Kissin DM. Effects of patient education on desire for twins and use of elective single embryo transfer procedures during ART treatment: a systematic review. Reprod Biomed Soc Online 2018;6:102-19. PMID:30761357 https://doi.org/10.1016/j. rbms.2018.10.017

52. Kulkarni AD, Jamieson DJ, Jones HW Jr, et al. Fertility treatments and multiple births in the United States. N Engl J Med 2013;369:2218-25. PMID:24304051 https://doi.org/10.1056/NEJMoa1301467

53. Callaghan WM, MacDorman MF, Rasmussen SA, Qin C, Lackritz EM. The contribution of preterm birth to infant mortality rates in the United States. Pediatrics 2006;118:1566-73. PMID:17015548 https:// doi.org/10.1542/peds.2006-0860

54. Tanner K, Sabrine N, Wren C. Cardiovascular malformations among preterm infants. Pediatrics 2005;116:e833-8. PMID:16322141 https:// doi.org/10.1542/peds.2005-0397

55. Rasmussen SA, Moore CA, Paulozzi LJ, Rhodenhiser EP. Risk for birth defects among premature infants: a population-based study. J Pediatr 2001;138:668-73. PMID:11343041 https://doi.org/10.1067/ mpd.2001.112249

56. Kissin DM, Jamieson DJ, Barfield WD. Monitoring health outcomes of assisted reproductive technology. N Engl J Med 2014;371:91-3. PMID:24988584 https://doi.org/10.1056/NEJMc1404371

57. Dunietz GL, Holzman C, Zhang Y, et al. Assisted reproductive technology and newborn size in singletons resulting from fresh and cryopreserved embryos transfer. PLoS One 2017;12:e0169869. PMID:28114395 https://doi.org/10.1371/journal.pone.0169869

58. D’Angelo DV, Whitehead N, Helms K, Barfield W, Ahluwalia IB. Birth outcomes of intended pregnancies among women who used assisted reproductive technology, ovulation stimulation, or no treatment. Fertil Steril 2011;96:314-320.e2. PMID:21718990 https://doi.org/10.1016/j. fertnstert.2011.05.073 
59. Martin JA, Hamilton BE, Osterman MJ. Three decades of twin births in the United States, 1980-2009. NCHS Data Brief 2012;80:1-8. PMID:22617378

60. Adashi EY, Gutman R. Delayed childbearing as a growing, previously unrecognized contributor to the national plural birth excess. Obstet Gynecol 2018;132:999-1006. PMID:30204699 https://doi. org/10.1097/AOG.0000000000002853

61. Sunderam S, Kissin DM, Crawford SB, Kulkarni AD, Boulet SL. Overview of 2015 U.S. assisted reproductive technology (ART) treatment outcomes and contribution of ART and non-ART fertility treatments to U.S. multiple births. Fertil Steril 2017;108(Suppl):e97-8. https://doi.org/10.1016/j.fertnstert.2017.07.297
62. Kulkarni AD, Adashi EY, Jamieson DJ, Crawford SB, Sunderam S, Kissin DM. Affordability of fertility treatments and multiple births in the United States. Paediatr Perinat Epidemiol 2017;31:438-48. PMID:28762537 https://doi.org/10.1111/ppe.12383

63. Barradas DT, Barfield WD, Wright V, D’Angelo D, Manning SE, Schieve LA. Assessment of assisted reproductive technology use questions: Pregnancy Risk Assessment Monitoring System Survey, 2004. Public Health Rep 2012;127:516-23. PMID:22942469 https://doi. org/10.1177/003335491212700507

64. Sanders J, Simonsen S, Porucznik CA, Baksh L, Stanford JB. Use of fertility treatments in relation to the duration of pregnancy attempt among women who were trying to become pregnant and experienced a live birth. Matern Child Health J 2014;18:258-67. PMID:23584927 https://doi.org/10.1007/s10995-013-1262-5 
TABLE 1. Number* and outcomes of assisted reproductive technology procedures in which at least one embryo was transferred, by female patient's reporting area of residence ${ }^{\dagger}$ at time of treatment — United States and Puerto Rico, 2017

\begin{tabular}{|c|c|c|c|c|c|c|c|c|c|}
\hline $\begin{array}{l}\text { Patient's } \\
\text { reporting } \\
\text { area of } \\
\text { residence }\end{array}$ & $\begin{array}{l}\text { No. of } \\
\text { ART } \\
\text { clinics }^{\S}\end{array}$ & $\begin{array}{c}\text { No. of } \\
\text { ART } \\
\text { procedures } \\
\text { performed }\end{array}$ & $\begin{array}{c}\text { No. of } \\
\text { ART } \\
\text { embryo-transfer } \\
\text { procedures }\end{array}$ & $\begin{array}{c}\text { No. of } \\
\text { ART } \\
\text { pregnancies }\end{array}$ & $\begin{array}{c}\text { No. of } \\
\text { ART } \\
\text { live-birth } \\
\text { deliveries }\end{array}$ & $\begin{array}{l}\text { No. of } \\
\text { ART singleton } \\
\text { live-birth } \\
\text { deliveries }\end{array}$ & $\begin{array}{l}\text { No. of } \\
\text { ART multiple } \\
\text { live-birth } \\
\text { deliveries }\end{array}$ & $\begin{array}{l}\text { No. of } \\
\text { ART } \\
\text { live-born } \\
\text { infants }\end{array}$ & $\begin{array}{l}\text { ART procedures } \\
\text { per } 1 \text { million } \\
\text { women aged } \\
15-44 \text { yrs }^{* *}\end{array}$ \\
\hline Alabama & 5 & 969 & 736 & 400 & 326 & 265 & 61 & 391 & 1,020 \\
\hline Alaska & 0 & 162 & 136 & 87 & 73 & 58 & 15 & 88 & 1,109 \\
\hline Arizona & 15 & 2,956 & 2,428 & 1,334 & 1,095 & 876 & 219 & 1,321 & 2,197 \\
\hline Arkansas & 1 & 607 & 468 & 234 & 199 & 146 & 53 & 253 & 1,051 \\
\hline California & 68 & 24,179 & 19,425 & 10,779 & 8,852 & 7,789 & 1,063 & 9,926 & 2,983 \\
\hline Colorado & 8 & 2,350 & 2,116 & 1,408 & 1,184 & 1,013 & 171 & 1,355 & 2,066 \\
\hline Connecticut & 6 & 3,518 & 2,690 & 1,544 & 1,271 & 1,102 & 169 & 1,440 & 5,228 \\
\hline Delaware & 2 & 744 & 535 & 304 & 219 & 214 & 5 & 224 & 4,126 \\
\hline District of Columbia & 2 & 1,269 & 958 & 457 & 375 & 351 & 24 & 399 & 6,806 \\
\hline Florida & 26 & 8,535 & 6,616 & 3,383 & 2,798 & 2,377 & 421 & 3,222 & 2,229 \\
\hline Georgia & 8 & 4,264 & 3,673 & 2,014 & 1,657 & 1,440 & 217 & 1,875 & 1,986 \\
\hline Hawaii & 5 & 1,010 & 802 & 430 & 341 & 258 & 83 & 426 & 3,798 \\
\hline Idaho & 1 & 619 & 522 & 296 & 244 & 194 & 50 & 293 & 1,882 \\
\hline Illinois ${ }^{\dagger \dagger}$ & 25 & 12,739 & 9,918 & 5,017 & 3,965 & 3,493 & 472 & 4,439 & 5,031 \\
\hline Indiana & 9 & 2,227 & 1,786 & 841 & 682 & 562 & 120 & 804 & 1,719 \\
\hline lowa & 2 & 1,451 & 1,186 & 715 & 599 & 535 & 64 & 663 & 2,450 \\
\hline Kansas & 4 & 1,001 & 830 & 469 & 383 & 337 & 46 & 429 & 1,792 \\
\hline Kentucky & 4 & 1,431 & 1,168 & 534 & 435 & 364 & 71 & 505 & 1,687 \\
\hline Louisiana & 5 & 1,517 & 1,135 & 600 & 502 & 434 & 68 & 571 & 1,621 \\
\hline Maine & 1 & 513 & 441 & 229 & 191 & 167 & 24 & 216 & 2,216 \\
\hline Maryland & 7 & 6,659 & 5,137 & 2,581 & 1,996 & 1,828 & 168 & 2,170 & 5,580 \\
\hline Massachusetts ${ }^{\dagger \dagger}$ & 9 & 10,178 & 8,424 & 4,011 & 3,263 & 2,985 & 278 & 3,548 & 7,366 \\
\hline Michigan & 11 & 3,939 & 3,184 & 1,730 & 1,426 & 1,130 & 296 & 1,728 & 2,102 \\
\hline Minnesota & 5 & 3,066 & 2,694 & 1,499 & 1,239 & 1,061 & 178 & 1,418 & 2,874 \\
\hline Mississippi & 2 & 579 & 485 & 262 & 220 & 196 & 24 & 245 & 979 \\
\hline Missouri & 9 & 2,131 & 1,768 & 914 & 774 & 620 & 154 & 932 & 1,819 \\
\hline Montana & 1 & 306 & 264 & 156 & 133 & 116 & 17 & 150 & 1,610 \\
\hline Nebraska & 2 & 831 & 657 & 360 & 297 & 243 & 54 & 352 & 2,245 \\
\hline Nevada & 5 & 1,181 & 996 & 571 & 447 & 388 & 59 & 509 & 2,005 \\
\hline New Hampshire & 0 & 998 & 851 & 419 & 362 & 312 & 50 & 413 & 4,135 \\
\hline New Jersey ${ }^{\dagger \dagger}$ & 19 & 10,562 & 8,317 & 4,799 & 3,940 & 3,599 & 341 & 4,285 & 6,158 \\
\hline New Mexico & 2 & 367 & 342 & 185 & 159 & 132 & 27 & 187 & 928 \\
\hline New York & 40 & 23,270 & 17,933 & 8,644 & 6,957 & 6,166 & 791 & 7,758 & 5,816 \\
\hline North Carolina & 10 & 4,306 & 3,371 & 1,988 & 1,601 & 1,369 & 232 & 1,838 & 2,135 \\
\hline North Dakota & 1 & 262 & 236 & 138 & 121 & 91 & 30 & 151 & 1,791 \\
\hline Ohio & 11 & 4,687 & 3,727 & 2,002 & 1,637 & 1,443 & 194 & 1,837 & 2,127 \\
\hline Oklahoma & 3 & 944 & 762 & 364 & 303 & 247 & 56 & 359 & 1,228 \\
\hline Oregon & 3 & 1,273 & 1,144 & 752 & 641 & 525 & 116 & 761 & 1,571 \\
\hline Pennsylvania & 15 & 7,082 & 5,586 & 2,883 & 2,317 & 2,084 & 233 & 2,554 & 2,971 \\
\hline Puerto Rico & 3 & 222 & 194 & 96 & 67 & 49 & 18 & 85 & 338 \\
\hline Rhode Island ${ }^{\dagger+}$ & 1 & 950 & 806 & 328 & 273 & 250 & 23 & 296 & 4,544 \\
\hline South Carolina & 4 & 1,713 & 1,315 & 695 & 566 & 483 & 83 & 645 & 1,774 \\
\hline South Dakota & 1 & 282 & 242 & 134 & 111 & 92 & 19 & 130 & 1,775 \\
\hline Tennessee & 10 & 1,789 & 1,434 & 797 & 662 & 572 & 90 & 756 & 1,363 \\
\hline Texas & 41 & 14,594 & 11,849 & 6,581 & 5,374 & 4,577 & 797 & 6,185 & 2,480 \\
\hline Utah & 3 & 2,184 & 1,923 & 1,116 & 925 & 764 & 161 & 1,087 & 3,235 \\
\hline Vermont & 2 & 368 & 301 & 143 & 109 & 94 & 15 & 123 & 3,232 \\
\hline Virginia & 10 & 6,149 & 4,924 & 2,649 & 2,137 & 1,916 & 221 & 2,360 & 3,658 \\
\hline Washington & 12 & 3,909 & 3,053 & 1,830 & 1,517 & 1,362 & 155 & 1,672 & 2,669 \\
\hline West Virginia & 3 & 341 & 270 & 123 & 96 & 77 & 19 & 115 & 1,058 \\
\hline Wisconsin & 6 & 2,027 & 1,683 & 903 & 801 & 664 & 137 & 941 & 1,870 \\
\hline Wyoming & 0 & 169 & 148 & 90 & 74 & 56 & 18 & 93 & 1,569 \\
\hline Non-U.S. resident & - & 7,075 & 5,910 & 3,522 & 2,972 & 2,425 & 547 & 3,529 & —§§ \\
\hline Total & 448 & 196,454 & 157,499 & 84,340 & 68,908 & 59,891 & 9,017 & 78,052 & 3,040 \\
\hline
\end{tabular}

Abbreviation: ART = assisted reproductive technology.

* Total number of cycles reported to CDC was 284,403 . This report excludes 87,931 cycles in which egg or embryo banking was performed and 18 research cycles.

$\dagger$ In cases of missing residency data $(0.3 \%)$, the patient's residence was assigned as the location where the ART procedure was performed.

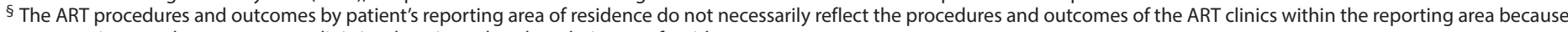
some patients seek treatment at a clinic in a location other than their area of residence.

I Embryo-transfer procedures include all procedures performed in which an attempt was made to transfer at least one embryo.

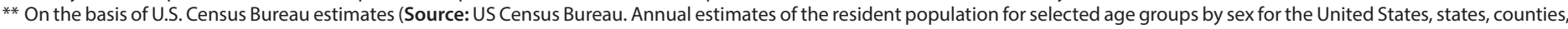

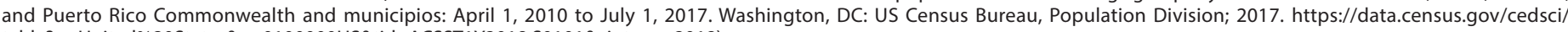
table?q=United\%20States\&g=0100000US\&tid=ACSST1Y2018.S0101\&vintage=2018).

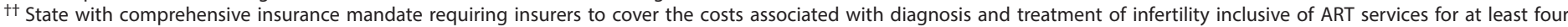
oocyte retrievals.

$\S \S$ Non-U.S. residents were excluded from rate because the appropriate denominators were not available. 
TABLE 2. Number of assisted reproductive technology embryo-transfer procedures with a single-embryo transfer, ${ }^{*}$ by female patient's age group and reporting area of residence ${ }^{\dagger}$ at time of treatment — United States and Puerto Rico, 2017

\begin{tabular}{|c|c|c|c|c|c|c|c|c|c|}
\hline \multirow[b]{2}{*}{$\begin{array}{l}\text { Patient's reporting } \\
\text { area of residence }\end{array}$} & \multicolumn{3}{|c|}{$<35$ yrs } & \multicolumn{3}{|c|}{$35-37$ yrs } & \multicolumn{3}{|c|}{$>37$ yrs } \\
\hline & $\begin{array}{c}\text { No. of } \\
\text { embryo-transfer } \\
\text { procedures }\end{array}$ & $\begin{array}{c}\text { Average no. of } \\
\text { embryos } \\
\text { transferred }\end{array}$ & $\begin{array}{l}\text { SET } \\
(\%)\end{array}$ & $\begin{array}{c}\text { No. of } \\
\text { embryo-transfer } \\
\text { procedures }\end{array}$ & $\begin{array}{l}\text { Average no. } \\
\text { of embryos } \\
\text { transferred }\end{array}$ & $\begin{array}{l}\text { SET } \\
(\%)\end{array}$ & $\begin{array}{c}\text { No. of } \\
\text { embryo-transfer } \\
\text { procedures }\end{array}$ & $\begin{array}{l}\text { Average no. } \\
\text { of embryos } \\
\text { transferred }\end{array}$ & $\begin{array}{l}\text { SET } \\
(\%)\end{array}$ \\
\hline Alabama & 388 & 1.5 & 55.4 & 149 & 1.5 & 54.4 & 199 & 1.7 & 48.2 \\
\hline Alaska & 49 & 1.3 & 71.4 & 34 & 1.3 & 73.5 & 53 & 1.4 & 64.2 \\
\hline Arizona & 1,124 & 1.6 & 47.8 & 574 & 1.6 & 51.4 & 730 & 1.7 & 50.7 \\
\hline Arkansas & 296 & 1.5 & 50.3 & 90 & 1.6 & 43.3 & 82 & 1.5 & 52.4 \\
\hline California & 6,030 & 1.3 & 68.4 & 4,637 & 1.3 & 68.5 & 8,758 & 1.5 & 63.3 \\
\hline Colorado & 898 & 1.3 & 68.6 & 518 & 1.3 & 68.0 & 700 & 1.3 & 72.7 \\
\hline Connecticut & 1,048 & 1.2 & 77.7 & 629 & 1.4 & 63.6 & 1,013 & 1.6 & 53.4 \\
\hline Delaware & 250 & 1.1 & 90.4 & 113 & 1.1 & 89.4 & 172 & 1.2 & 83.1 \\
\hline District of Columbia & 201 & 1.1 & 86.6 & 220 & 1.2 & 80.9 & 537 & 1.4 & 69.5 \\
\hline Florida & 2,767 & 1.4 & 64.7 & 1,492 & 1.4 & 59.0 & 2,357 & 1.5 & 55.5 \\
\hline Georgia & 1,528 & 1.3 & 71.1 & 843 & 1.4 & 66.3 & 1,302 & 1.4 & 66.5 \\
\hline Hawaii & 253 & 1.6 & 40.7 & 197 & 1.6 & 39.6 & 352 & 1.9 & 36.9 \\
\hline Idaho & 276 & 1.5 & 47.5 & 122 & 1.4 & 57.4 & 124 & 1.5 & 58.1 \\
\hline Illinois§ & 4,252 & 1.4 & 65.8 & 2,361 & 1.4 & 59.9 & 3,305 & 1.6 & 53.8 \\
\hline Indiana & 1,001 & 1.4 & 57.8 & 360 & 1.5 & 55.3 & 425 & 1.5 & 54.6 \\
\hline lowa & 720 & 1.3 & 74.0 & 224 & 1.3 & 74.6 & 242 & 1.4 & 63.6 \\
\hline Kansas & 473 & 1.3 & 73.6 & 173 & 1.3 & 70.5 & 184 & 1.3 & 70.1 \\
\hline Kentucky & 707 & 1.5 & 56.4 & 214 & 1.5 & 58.9 & 247 & 1.6 & 47.4 \\
\hline Louisiana & 596 & 1.4 & 61.9 & 275 & 1.4 & 56.4 & 264 & 1.5 & 61.4 \\
\hline Maine & 225 & 1.3 & 72.9 & 97 & 1.4 & 66.0 & 119 & 1.3 & 72.3 \\
\hline Maryland & 2,050 & 1.2 & 77.6 & 1,184 & 1.3 & 72.0 & 1,903 & 1.5 & 61.7 \\
\hline Massachusetts $\S$ & 3,312 & 1.2 & 85.1 & 2,070 & 1.2 & 77.9 & 3,042 & 1.6 & 55.7 \\
\hline Michigan & 1,574 & 1.6 & 44.7 & 702 & 1.6 & 45.6 & 908 & 1.7 & 46.1 \\
\hline Minnesota & 1,334 & 1.4 & 63.0 & 602 & 1.4 & 58.5 & 758 & 1.4 & 61.1 \\
\hline Mississippi & 269 & 1.3 & 75.8 & 98 & 1.5 & 53.1 & 118 & 1.5 & 61.0 \\
\hline Missouri & 1,004 & 1.5 & 50.2 & 398 & 1.5 & 52.3 & 366 & 1.7 & 48.6 \\
\hline Montana & 120 & 1.3 & 71.7 & 62 & 1.3 & 71.0 & 82 & 1.5 & 61.0 \\
\hline Nebraska & 395 & 1.4 & 57.2 & 125 & 1.5 & 55.2 & 137 & 1.5 & 58.4 \\
\hline Nevada & 463 & 1.4 & 58.7 & 198 & 1.3 & 70.7 & 335 & 1.4 & 66.3 \\
\hline New Hampshire & 399 & 1.2 & 76.2 & 230 & 1.3 & 71.7 & 222 & 1.6 & 54.1 \\
\hline New Jersey ${ }^{\S}$ & 3,277 & 1.2 & 78.8 & 1,950 & 1.3 & 73.7 & 3,090 & 1.4 & 69.8 \\
\hline New Mexico & 155 & 1.4 & 65.8 & 83 & 1.3 & 72.3 & 104 & 1.4 & 66.3 \\
\hline New York & 6,227 & 1.3 & 68.4 & 3,780 & 1.4 & 64.4 & 7,926 & 1.6 & 57.4 \\
\hline North Carolina & 1,557 & 1.3 & 68.3 & 813 & 1.4 & 62.2 & 1,001 & 1.5 & 55.5 \\
\hline North Dakota & 150 & 1.5 & 49.3 & 46 & 1.4 & 60.9 & 40 & 1.5 & 57.5 \\
\hline Ohio & 1,960 & 1.3 & 67.3 & 834 & 1.4 & 61.5 & 933 & 1.6 & 52.0 \\
\hline Oklahoma & 451 & 1.5 & 47.0 & 138 & 1.7 & 37.0 & 173 & 1.8 & 32.9 \\
\hline Oregon & 427 & 1.5 & 53.9 & 294 & 1.4 & 60.9 & 423 & 1.4 & 65.7 \\
\hline Pennsylvania & 2,572 & 1.3 & 73.7 & 1,336 & 1.3 & 68.1 & 1,678 & 1.4 & 64.8 \\
\hline Puerto Rico & 55 & 1.7 & 41.8 & 55 & 1.8 & 23.6 & 84 & 2.0 & 28.6 \\
\hline Rhode Island ${ }^{\S}$ & 326 & 1.2 & 81.6 & 193 & 1.3 & 72.0 & 287 & 1.8 & 44.3 \\
\hline South Carolina & 661 & 1.3 & 66.1 & 301 & 1.4 & 59.5 & 353 & 1.5 & 55.2 \\
\hline South Dakota & 167 & 1.6 & 38.9 & 48 & 1.6 & 37.5 & 27 & 1.6 & 48.1 \\
\hline Tennessee & 689 & 1.4 & 65.5 & 342 & 1.5 & 58.5 & 403 & 1.5 & 58.6 \\
\hline Texas & 5,537 & 1.4 & 64.2 & 2,741 & 1.4 & 63.1 & 3,571 & 1.5 & 60.8 \\
\hline Utah & 1,158 & 1.4 & 59.2 & 354 & 1.5 & 55.1 & 411 & 1.5 & 55.7 \\
\hline Vermont & 132 & 1.3 & 68.9 & 81 & 1.4 & 59.3 & 88 & 1.6 & 52.3 \\
\hline Virginia & 1,863 & 1.3 & 74.7 & 1,161 & 1.3 & 72.1 & 1,900 & 1.4 & 66.8 \\
\hline Washington & 1,218 & 1.3 & 72.7 & 736 & 1.3 & 75.0 & 1,099 & 1.3 & 73.4 \\
\hline West Virginia & 161 & 1.5 & 55.3 & 55 & 1.4 & 61.8 & 54 & 1.4 & 63.0 \\
\hline Wisconsin & 884 & 1.4 & 60.5 & 385 & 1.4 & 57.9 & 414 & 1.6 & 48.6 \\
\hline Wyoming & 77 & 1.4 & 55.8 & 34 & 1.6 & 44.1 & 37 & 1.4 & 59.5 \\
\hline Non-U.S. resident & 1,681 & 1.4 & 61.7 & 1,038 & 1.4 & 62.4 & 3,191 & 1.4 & 62.9 \\
\hline Total & 65,387 & 1.3 & 67.3 & 35,789 & 1.4 & 65.0 & 56,323 & 1.5 & 60.0 \\
\hline
\end{tabular}

Abbreviation: $\mathrm{SET}=$ single-embryo transfer.

* Includes all procedures in which at least one embryo was transferred.

$\dagger$ In cases of missing residency data $(0.3 \%)$, the patient's residence was assigned as the location where the assisted reproductive technology procedure was performed.

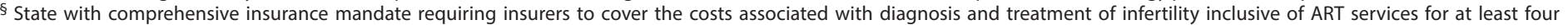
oocyte retrievals. 
TABLE 3. Number, proportion, and percentage of infants born with use of assisted reproductive technology, by female patient's reporting area of residence* at time of treatment - United States and Puerto Rico, 2017 ${ }^{\dagger}$

\begin{tabular}{|c|c|c|c|c|c|c|}
\hline \multirow{3}{*}{$\begin{array}{l}\text { Patient's reporting } \\
\text { area of residence }\end{array}$} & \multirow{3}{*}{$\begin{array}{c}\text { Total no. } \\
\text { of infants } \\
\text { born } \$, \emptyset\end{array}$} & \multirow{3}{*}{$\begin{array}{c}\text { No. of } \\
\text { ART infants } \\
\text { born }\end{array}$} & \multirow{3}{*}{$\begin{array}{l}\text { Proportion of } \\
\text { ART infants } \\
\text { among all } \\
\text { infants (\%) }\end{array}$} & \multicolumn{3}{|c|}{ Singleton infants } \\
\hline & & & & $\begin{array}{c}\text { ART } \\
\text { infants }\end{array}$ & $\begin{array}{c}\text { All } \\
\text { infants }\end{array}$ & $\begin{array}{l}\text { Proportion of } \\
\text { ART singleton infants }\end{array}$ \\
\hline & & & & No. (\%) & No. (\%) & infants (\%) \\
\hline Alabama & 58,941 & 388 & 0.7 & $253(65.2)$ & $56,770(96.3)$ & 0.4 \\
\hline Alaska & 10,445 & 81 & 0.8 & $61(75.3)$ & $10,142(97.1)$ & 0.6 \\
\hline Arizona & 81,872 & 1,424 & 1.7 & $871(61.2)$ & $79,200(96.7)$ & 1.1 \\
\hline Arkansas & 37,520 & 245 & 0.7 & $150(61.2)$ & $36,306(96.8)$ & 0.4 \\
\hline California & 471,658 & 9,844 & 2.1 & $7,459(75.8)$ & $456,782(96.8)$ & 1.6 \\
\hline Colorado & 64,382 & 1,298 & 2.0 & $937(72.2)$ & $62,346(96.8)$ & 1.5 \\
\hline Connecticut & 35,221 & 1,525 & 4.3 & $1,097(71.9)$ & $33,769(95.9)$ & 3.2 \\
\hline Delaware & 10,855 & 248 & 2.3 & $224(90.3)$ & $10,473(96.5)$ & 2.1 \\
\hline District of Columbia & 9,560 & 416 & 4.4 & $374(89.9)$ & $9,200(96.2)$ & 4.1 \\
\hline Florida & 223,630 & 3,296 & 1.5 & $2,248(68.2)$ & $216,180(96.7)$ & 1.0 \\
\hline Georgia & 129,243 & 1,771 & 1.4 & $1,339(75.6)$ & $124,669(96.5)$ & 1.1 \\
\hline Hawaii & 17,517 & 461 & 2.6 & $268(58.1)$ & $16,908(96.5)$ & 1.6 \\
\hline Idaho & 22,181 & 265 & 1.2 & $164(61.9)$ & $21,478(96.8)$ & 0.8 \\
\hline Illinois** & 149,390 & 4,463 & 3.0 & $3,326(74.5)$ & $143,869(96.3)$ & 2.3 \\
\hline Indiana & 82,170 & 796 & 1.0 & $545(68.5)$ & 79,380 (96.6) & 0.7 \\
\hline lowa & 38,430 & 642 & 1.7 & 505 (78.7) & $37,157(96.7)$ & 1.4 \\
\hline Kansas & 36,519 & 453 & 1.2 & $325(71.7)$ & $35,285(96.6)$ & 0.9 \\
\hline Kentucky & 54,752 & 527 & 1.0 & $357(67.7)$ & $52,879(96.6)$ & 0.7 \\
\hline Louisiana & 61,018 & 624 & 1.0 & $403(64.6)$ & $58,853(96.5)$ & 0.7 \\
\hline Maine & 12,298 & 215 & 1.7 & $160(74.4)$ & 11,911 (96.9) & 1.3 \\
\hline Maryland & 71,641 & 2,196 & 3.1 & $1,802(82.1)$ & $69,103(96.5)$ & 2.6 \\
\hline Massachusetts** & 70,702 & 3,557 & 5.0 & 2,974 (83.6) & 68,132 (96.4) & 4.4 \\
\hline Michigan & 111,426 & 1,689 & 1.5 & $1,032(61.1)$ & $107,123(96.1)$ & 1.0 \\
\hline Minnesota & 68,595 & 1,387 & 2.0 & 990 (71.4) & $66,177(96.5)$ & 1.5 \\
\hline Mississippi & 37,357 & 237 & 0.6 & 168 (70.9) & 36,089 (96.6) & 0.5 \\
\hline Missouri & 73,034 & 1,021 & 1.4 & $677(66.3)$ & $70,323(96.3)$ & 1.0 \\
\hline Montana & 11,799 & 152 & 1.3 & $96(63.2)$ & 11,414 (96.7) & 0.8 \\
\hline Nebraska & 25,821 & 369 & 1.4 & $245(66.4)$ & $24,816(96.1)$ & 1.0 \\
\hline Nevada & 35,756 & 575 & 1.6 & $401(69.7)$ & $34,623(96.8)$ & 1.2 \\
\hline New Hampshire & 12,116 & 306 & 2.5 & $248(81.0)$ & $11,663(96.3)$ & 2.1 \\
\hline New Jersey** & 101,250 & 4,176 & 4.1 & 3,365 (80.6) & $97,500(96.3)$ & 3.5 \\
\hline New Mexico & 23,767 & 155 & 0.7 & $100(64.5)$ & 23,142 (97.4) & 0.4 \\
\hline New York & 229,737 & 7,495 & 3.3 & $5,763(76.9)$ & $221,332(96.3)$ & 2.6 \\
\hline North Carolina & 120,125 & 1,890 & 1.6 & $1,281(67.8)$ & $115,762(96.4)$ & 1.1 \\
\hline North Dakota & 10,737 & 154 & 1.4 & $84(54.5)$ & 10,343 (96.3) & 0.8 \\
\hline Ohio & 136,832 & 1,827 & 1.3 & $1,276(69.8)$ & $131,943(96.4)$ & 1.0 \\
\hline Oklahoma & 50,214 & 389 & 0.8 & $251(64.5)$ & $48,651(96.9)$ & 0.5 \\
\hline Oregon & 43,631 & 757 & 1.7 & $473(62.5)$ & 42,073 (96.4) & 1.1 \\
\hline Pennsylvania & 137,745 & 2,593 & 1.9 & $1,984(76.5)$ & $132,873(96.5)$ & 1.5 \\
\hline Puerto Rico & 24,310 & 88 & 0.4 & $48(54.5)$ & 23,834 (98.0) & 0.2 \\
\hline Rhode Island ${ }^{* *}$ & 10,638 & 295 & 2.8 & 215 (72.9) & $10,267(96.5)$ & 2.1 \\
\hline South Carolina & 57,029 & 660 & 1.2 & 466 (70.6) & $55,029(96.5)$ & 0.8 \\
\hline South Dakota & 12,134 & 115 & 0.9 & 85 (73.9) & 11,693 (96.4) & 0.7 \\
\hline Tennessee & 81,016 & 753 & 0.9 & $564(74.9)$ & 78,394 (96.8) & 0.7 \\
\hline Texas & 382,050 & 6,164 & 1.6 & $4,254(69.0)$ & 369,730 (96.8) & 1.2 \\
\hline Utah & 48,585 & 1,005 & 2.1 & $681(67.8)$ & 46,831 (96.4) & 1.5 \\
\hline Vermont & 5,655 & 132 & 2.3 & $94(71.2)$ & $5,474(96.8)$ & 1.7 \\
\hline Virginia & 100,391 & 2,130 & 2.1 & $1,710(80.3)$ & $96,871(96.5)$ & 1.8 \\
\hline Washington & 87,562 & 1,594 & 1.8 & $1,278(80.2)$ & 84,864 (96.9) & 1.5 \\
\hline West Virginia & 18,675 & 140 & 0.7 & $93(66.4)$ & $18,076(96.8)$ & 0.5 \\
\hline Wisconsin & 64,975 & 946 & 1.5 & $620(65.5)$ & 62,671 (96.5) & 1.0 \\
\hline Wyoming & 6,903 & 77 & 1.1 & $52(67.5)$ & $6,734(97.6)$ & 0.8 \\
\hline Total & $3,879,810$ & 74,006 & 1.9 & 54,436 (73.6) & $3,747,107(96.6)$ & 1.5 \\
\hline
\end{tabular}

Abbreviation: ART = assisted reproductive technology.

* In cases of missing residency data $(0.3 \%)$, the patient's residence was assigned as the location where the ART procedure was performed.

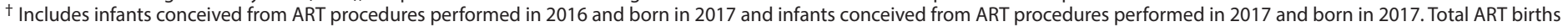
exclude births to non-U.S. residents.

$\S$ U.S. births include births to non-U.S. residents (Source: Martin JA, Hamilton BE, Osterman MJ, Driscoll AK, Drake P. Births: final data for 2017. Natl Vital Stat Rep 2018;67:1-50),

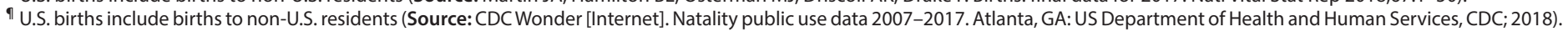

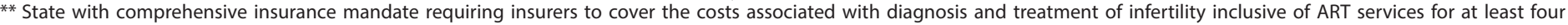
oocyte retrievals. 
TABLE 4. Number, percentage, and proportion of multiple-birth infants, twins, and triplets and higher-order infants born with use of assisted reproductive technology procedures, by female patient's reporting area of residence* at time of treatment — United States and Puerto Rico, $2017^{\dagger}$

\begin{tabular}{|c|c|c|c|c|c|c|c|c|c|}
\hline \multirow[b]{2}{*}{$\begin{array}{l}\text { Patient's } \\
\text { reporting } \\
\text { area of } \\
\text { residence }\end{array}$} & \multicolumn{3}{|c|}{ Multiple-birth infants } & \multicolumn{3}{|c|}{ Twin infants } & \multicolumn{3}{|c|}{ Triplets and higher-order infants } \\
\hline & $\begin{array}{c}\text { ART } \\
\text { infants }^{\S}\end{array}$ & $\begin{array}{c}\text { All } \\
\text { infants }\end{array}$ & $\begin{array}{l}\text { Proportion of } \\
\text { ART multiple } \\
\text { births among } \\
\text { all multiple } \\
\text { births (\%) }\end{array}$ & $\begin{array}{c}\text { ART } \\
\text { infants }^{\S}\end{array}$ & $\begin{array}{c}\text { All } \\
\text { infants }\end{array}$ & $\begin{array}{l}\text { Proportion of } \\
\text { ART twin infants } \\
\text { among } \\
\text { all twin } \\
\text { infants (\%) }\end{array}$ & $\begin{array}{c}\text { ART } \\
\text { infants }^{\S}\end{array}$ & $\begin{array}{c}\text { All } \\
\text { infants }\end{array}$ & $\begin{array}{l}\text { Proportion of } \\
\text { ART triplets and } \\
\text { higher-order infants } \\
\text { among all triplets } \\
\text { and higher-order } \\
\text { infants (\%) }\end{array}$ \\
\hline Alabama & $135(34.8)$ & $2,171(3.7)$ & 6.2 & $129(33.2)$ & $2,068(3.5)$ & 6.2 & $6(1.5)$ & $103(0.2)$ & 5.8 \\
\hline Alaska & $20(24.7)$ & -**(一) & —** & $20(24.7)$ & $297(2.8)$ & 6.7 & $0(0.0)$ & - $^{* *}(-)$ & - \\
\hline Arizona & $553(38.8)$ & $2,672(3.3)$ & 20.7 & $525(36.9)$ & $2,581(3.2)$ & 20.3 & $28(2.0)$ & $91(0.1)$ & 30.8 \\
\hline Arkansas & $95(38.8)$ & $1,214(3.2)$ & 7.8 & —**(一) & $1,193(3.2)$ & - ** & -**(一) & $21(0.1)$ & —** \\
\hline California & $2,385(24.2)$ & $14,876(3.2)$ & 16.0 & $2,320(23.6)$ & $14,495(3.1)$ & 16.0 & $65(0.7)$ & $381(0.1)$ & 17.1 \\
\hline Colorado & $361(27.8)$ & $2,036(3.2)$ & 17.7 & $346(26.7)$ & $1,985(3.1)$ & 17.4 & $15(1.2)$ & $51(0.1)$ & 29.4 \\
\hline Connecticut & $428(28.1)$ & $1,452(4.1)$ & 29.5 & $419(27.5)$ & $1,426(4.0)$ & 29.4 & $9(0.6)$ & $26(0.1)$ & 34.6 \\
\hline Delaware & $24(9.7)$ & - $^{* *}(-)$ & —** & $24(9.7)$ & 379 (3.5) & 6.3 & $0(0.0)$ & - $^{* *}(-)$ & - $^{\dagger+}$ \\
\hline $\begin{array}{l}\text { District of } \\
\text { Columbia }\end{array}$ & $42(10.1)$ & - $^{* *}(-)$ & 一 $^{* *}$ & $42(10.1)$ & $358(3.7)$ & 11.7 & $0(0.0)$ & - $^{*}(-)$ & $-^{t+}$ \\
\hline Florida & $1,048(31.8)$ & $7,450(3.3)$ & 14.1 & $1,031(31.3)$ & $7,288(3.3)$ & 14.1 & $17(0.5)$ & $162(0.1)$ & 10.5 \\
\hline Georgia & $432(24.4)$ & $4,574(3.5)$ & 9.4 & $413(23.3)$ & $4,456(3.4)$ & 9.3 & $19(1.1)$ & $118(0.1)$ & 16.1 \\
\hline Hawaii & $193(41.9)$ & 609 (3.5) & 31.7 & $184(39.9)$ & $597(3.4)$ & 30.8 & $9(2.0)$ & $12(0.1)$ & - \\
\hline Idaho & $101(38.1)$ & 703 (3.2) & 14.4 & —**(一) & $691(3.1)$ & 一** & 一** $^{* *}(-)$ & $12(0.1)$ & 一**,t† \\
\hline Illinois & $1,137(25.5)$ & $5,521(3.7)$ & 20.6 & $1,105(24.8)$ & 5,337 (3.6) & 20.7 & $32(0.7)$ & $184(0.1)$ & 17.4 \\
\hline Indiana & 251 (31.5) & $2,790(3.4)$ & 9.0 & $236(29.6)$ & $2,660(3.2)$ & 8.9 & $15(1.9)$ & $130(0.2)$ & 11.5 \\
\hline lowa & $137(21.3)$ & $1,273(3.3)$ & 10.8 & $137(21.3)$ & $1,234(3.2)$ & 11.1 & $0(0.0)$ & $39(0.1)$ & 0.0 \\
\hline Kansas & $128(28.3)$ & $1,234(3.4)$ & 10.4 & $128(28.3)$ & $1,216(3.3)$ & 10.5 & $0(0.0)$ & $18(0.0)$ & - \\
\hline Kentucky & $170(32.3)$ & $1,873(3.4)$ & 9.1 & $164(31.1)$ & $1,834(3.3)$ & 8.9 & $6(1.1)$ & $39(0.1)$ & 15.4 \\
\hline Louisiana & $221(35.4)$ & $2,165(3.5)$ & 10.2 & 209 (33.5) & $2,099(3.4)$ & 10.0 & $12(1.9)$ & $66(0.1)$ & 18.2 \\
\hline Maine & $55(25.6)$ & - $^{* *}(-)$ & —** & $55(25.6)$ & $378(3.1)$ & 14.6 & $0(0.0)$ & - $^{* *}(-)$ & —十+ \\
\hline Maryland & 394 (17.9) & $2,538(3.5)$ & 15.5 & $367(16.7)$ & $2,457(3.4)$ & 14.9 & $27(1.2)$ & $81(0.1)$ & 33.3 \\
\hline Massachusetts & $583(16.4)$ & $2,570(3.6)$ & 22.7 & $568(16.0)$ & $2,523(3.6)$ & 22.5 & $15(0.4)$ & $47(0.1)$ & 31.9 \\
\hline Michigan & 657 (38.9) & 4,303 (3.9) & 15.3 & $642(38.0)$ & $4,162(3.7)$ & 15.4 & $15(0.9)$ & $141(0.1)$ & 10.6 \\
\hline Minnesota & 397 (28.6) & $2,418(3.5)$ & 16.4 & $384(27.7)$ & $2,347(3.4)$ & 16.4 & $13(0.9)$ & $71(0.1)$ & 18.3 \\
\hline Mississippi & $69(29.1)$ & $1,268(3.4)$ & 5.4 & —** (一) & $1,231(3.3)$ & 一* & —** (一) & $37(0.1)$ & 一** \\
\hline Missouri & 344 (33.7) & $2,711(3.7)$ & 12.7 & 326 (31.9) & 2,615 (3.6) & 12.5 & $18(1.8)$ & $96(0.1)$ & 18.8 \\
\hline Montana & $56(36.8)$ & - ${ }^{* *}(-)$ & —** & $56(36.8)$ & $382(3.2)$ & 14.7 & $0(0.0)$ & - $^{* *}(-)$ & - $^{\dagger+}$ \\
\hline Nebraska & $124(33.6)$ & 1,005 (3.9) & 12.3 & $118(32.0)$ & $953(3.7)$ & 12.4 & $6(1.6)$ & $52(0.2)$ & 11.5 \\
\hline Nevada & $174(30.3)$ & $1,133(3.2)$ & 15.4 & $165(28.7)$ & $1,100(3.1)$ & 15.0 & $9(1.6)$ & $33(0.1)$ & 27.3 \\
\hline New Hampshire & $58(19.0)$ & $453(3.7)$ & 12.8 & $52(17.0)$ & 437 (3.6) & 11.9 & $6(2.0)$ & $16(0.1)$ & - ${ }^{+\dagger}$ \\
\hline New Jersey & $811(19.4)$ & 3,750 (3.7) & 21.6 & 780 (18.7) & $3,642(3.6)$ & 21.4 & $31(0.7)$ & $108(0.1)$ & 28.7 \\
\hline New Mexico & $55(35.5)$ & $625(2.6)$ & 8.8 & 46 (29.7) & $600(2.5)$ & 7.7 & $9(5.8)$ & $25(0.1)$ & 36.0 \\
\hline New York & $1,732(23.1)$ & 8,405 (3.7) & 20.6 & $1,678(22.4)$ & $8,111(3.5)$ & 20.7 & $54(0.7)$ & $294(0.1)$ & 18.4 \\
\hline North Carolina & $609(32.2)$ & $4,363(3.6)$ & 14.0 & $586(31.0)$ & $4,241(3.5)$ & 13.8 & $23(1.2)$ & $122(0.1)$ & 18.9 \\
\hline North Dakota & $70(45.5)$ & 394 (3.7) & 17.8 & 70 (45.5) & 377 (3.5) & 18.6 & $0(0.0)$ & $17(0.2)$ & —† \\
\hline Ohio & $551(30.2)$ & 4,889 (3.6) & 11.3 & $530(29.0)$ & $4,741(3.5)$ & 11.2 & $21(1.1)$ & $148(0.1)$ & 14.2 \\
\hline Oklahoma & $138(35.5)$ & $1,563(3.1)$ & 8.8 & - $^{* *}(-)$ & $1,523(3.0)$ & 一** & - ${ }^{* *}(-)$ & $40(0.1)$ & —** \\
\hline Oregon & $284(37.5)$ & $1,558(3.6)$ & 18.2 & $272(35.9)$ & $1,515(3.5)$ & 18.0 & 12 (1.6) & $43(0.1)$ & 27.9 \\
\hline Pennsylvania & $609(23.5)$ & $4,872(3.5)$ & 12.5 & $591(22.8)$ & $4,738(3.4)$ & 12.5 & $18(0.7)$ & $134(0.1)$ & 13.4 \\
\hline Puerto Rico & $40(45.5)$ & $476(2.0)$ & 8.4 & 34 (38.6) & 464 (1.9) & 7.3 & $6(6.8)$ & $12(0.0)$ & - $^{+\dagger}$ \\
\hline Rhode Island & $80(27.1)$ & - $^{* *}(-)$ & —** & $80(27.1)$ & $363(3.4)$ & 22.0 & $0(0.0)$ & - $^{* *}(-)$ & $-^{\dagger \dagger}$ \\
\hline South Carolina & $194(29.4)$ & $2,000(3.5)$ & 9.7 & - ${ }^{* *}(-)$ & $1,950(3.4)$ & —** & - ${ }^{* *}(-)$ & $50(0.1)$ & - ** \\
\hline South Dakota & $30(26.1)$ & 441 (3.6) & 6.8 & $30(26.1)$ & $427(3.5)$ & 7.0 & $0(0.0)$ & $14(0.1)$ & $-^{+\dagger}$ \\
\hline Tennessee & $189(25.1)$ & $2,622(3.2)$ & 7.2 & —** (一) & $2,538(3.1)$ & —** & —** (一) & $84(0.1)$ & - ** \\
\hline Texas & $1,910(31.0)$ & $12,320(3.2)$ & 15.5 & $1,822(29.6)$ & $11,926(3.1)$ & 15.3 & $88(1.4)$ & $394(0.1)$ & 22.3 \\
\hline Utah & $324(32.2)$ & $1,754(3.6)$ & 18.5 & 309 (30.7) & $1,690(3.5)$ & 18.3 & $15(1.5)$ & $64(0.1)$ & 23.4 \\
\hline Vermont & $38(28.8)$ & - $^{* *}(-)$ & —** & $38(28.8)$ & $176(3.1)$ & 21.6 & $0(0.0)$ & - ${ }^{* *}(-)$ & — \\
\hline Virginia & $420(19.7)$ & $3,520(3.5)$ & 11.9 & 408 (19.2) & $3,410(3.4)$ & 12.0 & $12(0.6)$ & $110(0.1)$ & 10.9 \\
\hline Washington & 316 (19.8) & $2,698(3.1)$ & 11.7 & 303 (19.0) & $2,607(3.0)$ & 11.6 & $13(0.8)$ & $91(0.1)$ & 14.3 \\
\hline West Virginia & 47 (33.6) & 599 (3.2) & 7.8 & - ${ }^{* *}(-)$ & $576(3.1)$ & —** & - ${ }^{* *}(-)$ & $23(0.1)$ & —** \\
\hline Wisconsin & $326(34.5)$ & $2,304(3.5)$ & 14.1 & $314(33.2)$ & $2,224(3.4)$ & 14.1 & $12(1.3)$ & $80(0.1)$ & 15.0 \\
\hline Wyoming & $25(32.5)$ & $169(2.4)$ & 14.8 & —* $^{* *}(-)$ & $156(2.3)$ & - ${ }^{* *}$ & -** $(-)$ & $13(0.2)$ & - $^{* *,+\dagger}$ \\
\hline Total & $19,570(26.4)$ & $132,703(3.4)$ & 14.7 & $18,890(25.5)$ & $128,774(3.3)$ & 14.7 & $680(0.9)$ & $3,929(0.1)$ & 17.3 \\
\hline
\end{tabular}

Abbreviation: ART = assisted reproductive technology.

* In cases of missing residency data $(0.3 \%)$, the patient's residence was assigned as the location where the ART procedure was performed.

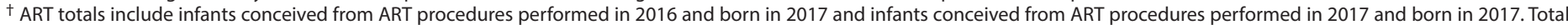
ART births exclude births to non-U.S. residents.

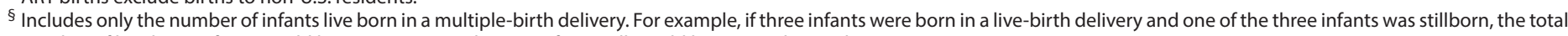
number of live-born infants would be two. However, the two infants still would be counted as triplets.

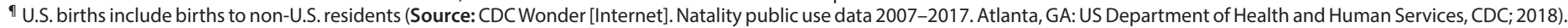

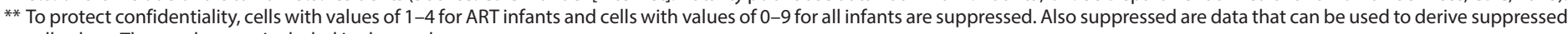
cell values. These values are included in the totals.

${ }^{+\dagger}$ Estimates on the basis of $\mathrm{N}<20$ in the denominator have been suppressed because such rates are considered unstable. 
TABLE 5. Number, percentage, and proportion of infants born with use of assisted reproductive technology, ${ }^{*}$ by low birthweight category and female patient's reporting area of residence ${ }^{\dagger}$ at time of treatment — United States and Puerto Rico, 2017

\begin{tabular}{|c|c|c|c|c|c|c|c|c|c|}
\hline \multirow[b]{3}{*}{$\begin{array}{l}\text { Patient's } \\
\text { reporting } \\
\text { area of } \\
\text { residence }\end{array}$} & \multicolumn{3}{|c|}{$<1,500 \mathrm{~g}(\mathrm{VLBW})$} & \multicolumn{3}{|c|}{$1,500-2,499 \mathrm{~g}$ (MLBW) } & \multicolumn{3}{|c|}{$<2,500 \mathrm{~g}(\mathrm{LBW})$} \\
\hline & $\begin{array}{c}\text { ART } \\
\text { infants }\end{array}$ & $\begin{array}{c}\text { All } \\
\text { infants }\end{array}$ & $\begin{array}{c}\text { Proportion } \\
\text { of ART }\end{array}$ & $\begin{array}{c}\text { ART } \\
\text { infants }\end{array}$ & $\begin{array}{c}\text { All } \\
\text { infants } \\
\end{array}$ & $\begin{array}{c}\text { Proportion of } \\
\text { ART }\end{array}$ & $\begin{array}{c}\text { ART } \\
\text { infants }\end{array}$ & $\begin{array}{c}\text { All } \\
\text { infants } \\
\end{array}$ & $\begin{array}{c}\text { Proportion of } \\
\text { ART }\end{array}$ \\
\hline & No. (\%) & No. (\%) & $\begin{array}{l}\text { VLBW infants } \\
\text { among all } \\
\text { VLBW infants } \\
(\%)\end{array}$ & No. (\%) & No. (\%) & $\begin{array}{l}\text { MLBW infants } \\
\text { among all } \\
\text { MLBW infants } \\
(\%)\end{array}$ & No. (\%) & No. (\%) & $\begin{array}{l}\text { LBW infants } \\
\text { among all } \\
\text { LBW infants } \\
\text { (\%) }\end{array}$ \\
\hline Alabama & $16(4.2)$ & $1,119(1.9)$ & 1.4 & $92(23.9)$ & $4,919(8.3)$ & 1.9 & $108(28.1)$ & $6,038(10.2)$ & 1.8 \\
\hline Alaska & $-9(-)$ & $104(1.0)$ & - & $-(-)$ & $543(5.2)$ & - & $19(23.5)$ & $647(6.2)$ & 2.9 \\
\hline Arizona & $41(3.0)$ & 952 (1.2) & 4.3 & 298 (21.9) & $5,167(6.3)$ & 5.8 & $339(24.9)$ & $6,119(7.5)$ & 5.5 \\
\hline Arkansas & $9(3.7)$ & $598(1.6)$ & 1.5 & $64(26.4)$ & $2,879(7.7)$ & 2.2 & $73(30.2)$ & $3,477(9.3)$ & 2.1 \\
\hline California & $273(2.9)$ & $5,191(1.1)$ & 5.3 & $1,472(15.4)$ & $27,260(5.8)$ & 5.4 & $1,745(18.3)$ & $32,451(6.9)$ & 5.4 \\
\hline Colorado & 49 (3.9) & 779 (1.2) & 6.3 & $270(21.5)$ & $5,069(7.9)$ & 5.3 & $319(25.4)$ & $5,848(9.1)$ & 5.5 \\
\hline Connecticut & $75(5.0)$ & $513(1.5)$ & 14.6 & $245(16.3)$ & $2,332(6.6)$ & 10.5 & $320(21.3)$ & $2,845(8.1)$ & 11.2 \\
\hline Delaware & $-(-)$ & $169(1.6)$ & - & $-(-)$ & $812(7.5)$ & - & $33(13.7)$ & $981(9.0)$ & 3.4 \\
\hline District of Columbia & $-(-)$ & $206(2.2)$ & - & $-(-)$ & $795(8.3)$ & - & $49(12.0)$ & $1,001(10.5)$ & 4.9 \\
\hline Florida & $113(3.5)$ & $3,433(1.5)$ & 3.3 & $613(19.2)$ & $16,220(7.3)$ & 3.8 & $726(22.7)$ & $19,653(8.8)$ & 3.7 \\
\hline Georgia & $66(3.8)$ & $2,319(1.8)$ & 2.8 & $292(16.7)$ & $10,453(8.1)$ & 2.8 & $358(20.5)$ & $12,772(9.9)$ & 2.8 \\
\hline Hawaii & $16(3.6)$ & 224 (1.3) & 7.1 & $108(24.6)$ & $1,267(7.2)$ & 8.5 & $124(28.2)$ & $1,491(8.5)$ & 8.3 \\
\hline Idaho & $9(3.5)$ & $231(1.0)$ & 3.9 & $56(21.5)$ & $1,314(5.9)$ & 4.3 & $65(25.0)$ & $1,545(7.0)$ & 4.2 \\
\hline Illinois & $156(3.6)$ & $2,131(1.4)$ & 7.3 & 709 (16.1) & $10,520(7.0)$ & 6.7 & 865 (19.7) & $12,651(8.5)$ & 6.8 \\
\hline Indiana & $26(3.3)$ & $1,152(1.4)$ & 2.3 & $148(19.0)$ & $5,642(6.9)$ & 2.6 & $174(22.3)$ & $6,794(8.3)$ & 2.6 \\
\hline lowa & $18(2.8)$ & $422(1.1)$ & 4.3 & 85 (13.4) & $2,104(5.5)$ & 4.0 & $103(16.2)$ & $2,526(6.6)$ & 4.1 \\
\hline Kansas & $16(3.7)$ & $476(1.3)$ & 3.4 & $68(15.8)$ & $2,209(6.0)$ & 3.1 & 84 (19.5) & $2,685(7.4)$ & 3.1 \\
\hline Kentucky & $17(3.3)$ & $827(1.5)$ & 2.1 & $93(18.0)$ & 4,004 (7.3) & 2.3 & $110(21.3)$ & $4,831(8.8)$ & 2.3 \\
\hline Louisiana & $29(4.8)$ & $1,138(1.9)$ & 2.5 & $147(24.1)$ & $5,381(8.8)$ & 2.7 & $176(28.9)$ & $6,519(10.7)$ & 2.7 \\
\hline Maine & $-(-)$ & $147(1.2)$ & - & $-(-)$ & $729(5.9)$ & - & 41 (19.2) & $876(7.1)$ & 4.7 \\
\hline Maryland & $90(4.1)$ & $1,261(1.8)$ & 7.1 & 301 (13.8) & $5,114(7.1)$ & 5.9 & 391 (17.9) & $6,375(8.9)$ & 6.1 \\
\hline Massachusetts & 65 (1.9) & 772 (1.1) & 8.4 & $430(12.5)$ & $4,488(6.3)$ & 9.6 & $495(14.4)$ & $5,260(7.4)$ & 9.4 \\
\hline Michigan & $62(3.7)$ & $1,637(1.5)$ & 3.8 & $340(20.6)$ & $8,156(7.3)$ & 4.2 & $402(24.3)$ & $9,793(8.8)$ & 4.1 \\
\hline Minnesota & $51(3.7)$ & $810(1.2)$ & 6.3 & $216(15.7)$ & $3,816(5.6)$ & 5.7 & $267(19.5)$ & $4,626(6.7)$ & 5.8 \\
\hline Mississippi & $5(2.1)$ & $780(2.1)$ & 0.6 & 39 (16.7) & $3,553(9.5)$ & 1.1 & 44 (18.9) & $4,333(11.6)$ & 1.0 \\
\hline Missouri & $44(4.6)$ & $1,087(1.5)$ & 4.0 & 190 (19.7) & $5,249(7.2)$ & 3.6 & $234(24.2)$ & $6,336(8.7)$ & 3.7 \\
\hline Montana & $-(-)$ & $122(1.0)$ & - & $-(-)$ & $820(6.9)$ & - & $36(24.0)$ & $942(8.0)$ & 3.8 \\
\hline Nebraska & $6(1.7)$ & $297(1.2)$ & 2.0 & $78(21.7)$ & $1,633(6.3)$ & 4.8 & $84(23.3)$ & $1,930(7.5)$ & 4.4 \\
\hline Nevada & $20(3.6)$ & $530(1.5)$ & 3.8 & $98(17.6)$ & $2,735(7.6)$ & 3.6 & $118(21.1)$ & $3,265(9.1)$ & 3.6 \\
\hline New Hampshire & $5(1.7)$ & $125(1.0)$ & 4.0 & 40 (13.2) & 714 (5.9) & 5.6 & 45 (14.9) & 839 (6.9) & 5.4 \\
\hline New Jersey & $128(3.2)$ & $1,366(1.3)$ & 9.4 & $592(14.6)$ & $6,674(6.6)$ & 8.9 & $720(17.8)$ & $8,040(7.9)$ & 9.0 \\
\hline New Mexico & $18(11.8)$ & $311(1.3)$ & 5.8 & $41(27.0)$ & $1,939(8.2)$ & 2.1 & $59(38.8)$ & $2,250(9.5)$ & 2.6 \\
\hline New York & 209 (3.0) & $3,200(1.4)$ & 6.5 & $1,089(15.5)$ & $15,343(6.7)$ & 7.1 & 1,298 (18.4) & $18,543(8.1)$ & 7.0 \\
\hline North Carolina & $77(4.4)$ & $2,025(1.7)$ & 3.8 & $311(17.7)$ & $9,243(7.7)$ & 3.4 & $388(22.1)$ & $11,268(9.4)$ & 3.4 \\
\hline North Dakota & $13(8.4)$ & $130(1.2)$ & 10.0 & $22(14.3)$ & $590(5.5)$ & 3.7 & $35(22.7)$ & $720(6.7)$ & 4.9 \\
\hline Ohio & $66(3.7)$ & $2,107(1.5)$ & 3.1 & $315(17.5)$ & $9,747(7.1)$ & 3.2 & $381(21.2)$ & $11,854(8.7)$ & 3.2 \\
\hline Oklahoma & $19(5.0)$ & $748(1.5)$ & 2.5 & 66 (17.4) & $3,337(6.6)$ & 2.0 & $85(22.4)$ & $4,085(8.1)$ & 2.1 \\
\hline Oregon & $20(2.8)$ & $449(1.0)$ & 4.5 & $150(20.8)$ & $2,523(5.8)$ & 5.9 & $170(23.5)$ & $2,972(6.8)$ & 5.7 \\
\hline Pennsylvania & $73(2.9)$ & $2,092(1.5)$ & 3.5 & 399 (15.9) & $9,488(6.9)$ & 4.2 & $472(18.8)$ & $11,580(8.4)$ & 4.1 \\
\hline Puerto Rico & $6(7.2)$ & 347 (1.4) & 1.7 & $25(30.1)$ & $2,209(9.1)$ & 1.1 & $31(37.3)$ & $2,556(10.5)$ & 1.2 \\
\hline Rhode Island & $13(4.5)$ & $158(1.5)$ & 8.2 & 41 (14.3) & $637(6.0)$ & 6.4 & $54(18.8)$ & 795 (7.5) & 6.8 \\
\hline South Carolina & $18(2.9)$ & $1,004(1.8)$ & 1.8 & $105(17.1)$ & 4,502 (7.9) & 2.3 & $123(20.0)$ & $5,506(9.7)$ & 2.2 \\
\hline South Dakota & $-(-)$ & $142(1.2)$ & - & $-(-)$ & $693(5.7)$ & - & $18(16.2)$ & 835 (6.9) & 2.2 \\
\hline Tennessee & $12(1.6)$ & $1,224(1.5)$ & 1.0 & 124 (16.9) & 6,185 (7.6) & 2.0 & $136(18.6)$ & $7,409(9.1)$ & 1.8 \\
\hline Texas & $295(4.9)$ & $5,437(1.4)$ & 5.4 & $1,150(19.1)$ & $26,725(7.0)$ & 4.3 & $1,445(24.0)$ & $32,162(8.4)$ & 4.5 \\
\hline Utah & $61(6.2)$ & $589(1.2)$ & 10.4 & 203 (20.6) & $2,918(6.0)$ & 7.0 & $264(26.8)$ & $3,507(7.2)$ & 7.5 \\
\hline Vermont & $6(4.6)$ & $62(1.1)$ & 9.7 & $13(9.9)$ & $318(5.6)$ & 4.1 & $19(14.5)$ & $380(6.7)$ & 5.0 \\
\hline Virginia & 74 (3.6) & $1,526(1.5)$ & 4.8 & $297(14.3)$ & $6,867(6.8)$ & 4.3 & $371(17.8)$ & $8,393(8.4)$ & 4.4 \\
\hline Washington & $31(2.0)$ & $860(1.0)$ & 3.6 & $224(14.2)$ & $4,916(5.6)$ & 4.6 & $255(16.2)$ & $5,776(6.6)$ & 4.4 \\
\hline West Virginia & $-(-)$ & $295(1.6)$ & - & $-(-)$ & $1,486(8.0)$ & - & $31(23.0)$ & $1,781(9.5)$ & 1.7 \\
\hline Wisconsin & $36(3.9)$ & 795 (1.2) & 4.5 & $163(17.5)$ & $4,173(6.4)$ & 3.9 & $199(21.4)$ & $4,968(7.6)$ & 4.0 \\
\hline Wyoming & $7(9.5)$ & $63(0.9)$ & 11.1 & $9(12.2)$ & $537(7.8)$ & 1.7 & $16(21.6)$ & $600(8.7)$ & 2.7 \\
\hline Total & $2,486(3.5)$ & $54,482(1.4)$ & 4.6 & $12,031(16.8)$ & $266,947(6.9)$ & 4.5 & $14,517(20.2)$ & $321,429(8.3)$ & 4.5 \\
\hline
\end{tabular}

Abbreviations: $A R T$ = assisted reproductive technology; LBW = low birthweight; MLBW = moderately low birthweight; VLBW = very low birthweight.

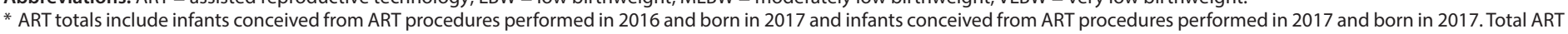
infants exclude births to non-U.S. residents and include only infants with birthweight data available.

+ In cases of missing residency data $(0.3 \%)$, the patient's residence was assigned as the location where the ART procedure was performed.

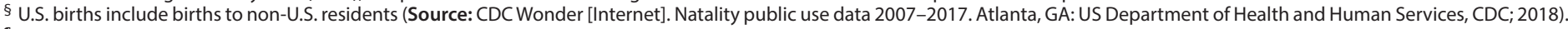

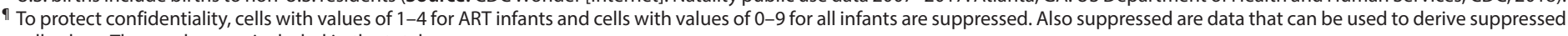
cell values. These values are included in the totals. 
TABLE 6. Number, percentage, and proportion of infants born with use of assisted reproductive technology,* by preterm gestational age category and female patient's reporting area of residence ${ }^{\dagger}$ at time of treatment — United States and Puerto Rico, 2017

\begin{tabular}{|c|c|c|c|c|c|c|c|c|c|c|c|c|}
\hline \multirow[b]{2}{*}{$\begin{array}{l}\text { Patient's } \\
\text { reporting } \\
\text { area of } \\
\text { residence }\end{array}$} & \multicolumn{3}{|c|}{ VPTB (<32 wks) } & \multicolumn{3}{|c|}{ Early PTB (<34 wks) } & \multicolumn{3}{|c|}{ Late PTB (34-36 wks) } & \multicolumn{3}{|c|}{ PTB (<37 wks) } \\
\hline & $\begin{array}{c}\text { ART } \\
\text { infants } \\
\end{array}$ & $\begin{array}{c}\text { All } \\
\text { infants } \\
\end{array}$ & $\begin{array}{l}\text { Proportion } \\
\text { of ART } \\
\text { VPTB } \\
\text { infants } \\
\text { among all } \\
\text { VPTB } \\
\text { infants } \\
(\%)\end{array}$ & $\begin{array}{c}\text { ART } \\
\text { infants }\end{array}$ & $\begin{array}{c}\text { All } \\
\text { infants } \\
\end{array}$ & $\begin{array}{l}\text { Proportion } \\
\text { of ART } \\
\text { early PTB } \\
\text { infants } \\
\text { among all } \\
\text { early PTB } \\
\text { infants } \\
(\%)\end{array}$ & $\begin{array}{c}\begin{array}{c}\text { ART } \\
\text { infants }\end{array} \\
\end{array}$ & $\begin{array}{c}\text { All } \\
\text { infants } \\
\end{array}$ & $\begin{array}{c}\text { Proportion } \\
\text { of ART } \\
\text { late PTB } \\
\text { infants } \\
\text { among all } \\
\text { late PTB } \\
\text { infants } \\
(\%)\end{array}$ & $\begin{array}{c}\text { ART } \\
\text { infants }\end{array}$ & $\begin{array}{l}\begin{array}{c}\text { All } \\
\text { infants }\end{array} \\
\end{array}$ & $\begin{array}{l}\text { Proportion } \\
\text { of ART } \\
\text { PTB } \\
\text { infants } \\
\text { among all } \\
\text { PTB } \\
\text { infants } \\
(\%)\end{array}$ \\
\hline Alabama & $25(6.5)$ & $1,167(2.0)$ & 2.1 & $40(10.3)$ & $2,001(3.4)$ & 2.0 & 111 (28.7) & $5,089(8.6)$ & 2.2 & $151(39.0)$ & $7,090(12.0)$ & 2.1 \\
\hline Alaska & $6(7.4)$ & $134(1.3)$ & 4.5 & $8(9.9)$ & $259(2.5)$ & 3.1 & $13(16.0)$ & $678(6.5)$ & 1.9 & $21(25.9)$ & $937(9.0)$ & 2.2 \\
\hline Arizona & $60(4.2)$ & $1,090(1.3)$ & 5.5 & $124(8.7)$ & $1,956(2.4)$ & 6.3 & $372(26.2)$ & $5,622(6.9)$ & 6.6 & 496 (34.9) & 7,578 (9.3) & 6.5 \\
\hline Arkansas & $17(6.9)$ & $673(1.8)$ & 2.5 & $36(14.7)$ & $1,165(3.1)$ & 3.1 & $69(28.2)$ & 3,103 (8.3) & 2.2 & 105 (42.9) & 4,268 (11.4) & 2.5 \\
\hline California & $380(3.9)$ & $5,999(1.3)$ & 6.3 & 744 (7.6) & $10,683(2.3)$ & 7.0 & 1,621 (16.6) & $30,224(6.4)$ & 5.4 & $2,365(24.2)$ & $40,907(8.7)$ & 5.8 \\
\hline Colorado & $64(5.0)$ & $831(1.3)$ & 7.7 & 136 (10.6) & $1,536(2.4)$ & 8.9 & 278 (21.6) & $4,102(6.4)$ & 6.8 & $414(32.2)$ & $5,638(8.8)$ & 7.3 \\
\hline Connecticut & $93(6.1)$ & $580(1.6)$ & 16.0 & $152(10.0)$ & $982(2.8)$ & 15.5 & 251 (16.5) & $2,356(6.7)$ & 10.7 & $403(26.5)$ & 3,338 (9.5) & 12.1 \\
\hline Delaware & $5(2.0)$ & $174(1.6)$ & 2.9 & $10(4.0)$ & $294(2.7)$ & 3.4 & $45(18.1)$ & 814 (7.5) & 5.5 & $55(22.2)$ & $1,108(10.2)$ & 5.0 \\
\hline $\begin{array}{l}\text { District of } \\
\text { Columbia }\end{array}$ & $8(1.9)$ & $213(2.2)$ & 3.8 & $14(3.4)$ & $354(3.7)$ & 4.0 & $48(11.6)$ & $662(6.9)$ & 7.3 & $62(15.0)$ & $1,016(10.6)$ & 6.1 \\
\hline Florida & $149(4.5)$ & $3,926(1.8)$ & 3.8 & $288(8.8)$ & $6,606(3.0)$ & 4.4 & 730 (22.2) & $16,245(7.3)$ & 4.5 & $1,018(31.0)$ & $22,851(10.2)$ & 4.5 \\
\hline Georgia & $88(5.0)$ & $2,633(2.0)$ & 3.3 & $175(9.9)$ & $4,243(3.3)$ & 4.1 & $375(21.3)$ & $10,513(8.1)$ & 3.6 & $550(31.3)$ & 14,756 (11.4) & 3.7 \\
\hline Hawaii & $20(4.4)$ & $265(1.5)$ & 7.5 & $47(10.2)$ & $475(2.7)$ & 9.9 & $104(22.7)$ & $1,354(7.7)$ & 7.7 & 151 (32.9) & $1,829(10.4)$ & 8.3 \\
\hline Idaho & $12(4.5)$ & $275(1.2)$ & 4.4 & $27(10.2)$ & $508(2.3)$ & 5.3 & $61(23.0)$ & $1,433(6.5)$ & 4.3 & $88(33.2)$ & $1,941(8.8)$ & 4.5 \\
\hline Illinois & $186(4.2)$ & $2,476(1.7)$ & 7.5 & $382(8.6)$ & 4,367 (2.9) & 8.7 & 768 (17.3) & $11,184(7.5)$ & 6.9 & $1,150(25.9)$ & $15,551(10.4)$ & 7.4 \\
\hline Indiana & $34(4.3)$ & $1,285(1.6)$ & 2.6 & $85(10.7)$ & $2,264(2.8)$ & 3.8 & $167(21.0)$ & $5,823(7.1)$ & 2.9 & $252(31.7)$ & $8,087(9.8)$ & 3.1 \\
\hline lowa & $21(3.3)$ & $487(1.3)$ & 4.3 & $46(7.2)$ & 898 (2.3) & 5.1 & 121 (18.9) & $2,626(6.8)$ & 4.6 & $167(26.1)$ & $3,524(9.2)$ & 4.7 \\
\hline Kansas & $29(6.4)$ & $583(1.6)$ & 5.0 & 49 (10.8) & $974(2.7)$ & 5.0 & 89 (19.6) & 2,521 (6.9) & 3.5 & $138(30.5)$ & 3,495 (9.6) & 3.9 \\
\hline Kentucky & $23(4.4)$ & $941(1.7)$ & 2.4 & $41(7.8)$ & $1,683(3.1)$ & 2.4 & 104 (19.7) & $4,409(8.1)$ & 2.4 & $145(27.5)$ & $6,092(11.1)$ & 2.4 \\
\hline Louisiana & $47(7.6)$ & $1,280(2.1)$ & 3.7 & $81(13.1)$ & $2,142(3.5)$ & 3.8 & 170 (27.4) & $5,583(9.1)$ & 3.0 & 251 (40.5) & 7,725 (12.7) & 3.2 \\
\hline Maine & $9(4.2)$ & $164(1.3)$ & 5.5 & $17(7.9)$ & $286(2.3)$ & 5.9 & $38(17.7)$ & $780(6.3)$ & 4.9 & $55(25.6)$ & $1,066(8.7)$ & 5.2 \\
\hline Maryland & $110(5.0)$ & $1,398(2.0)$ & 7.9 & $180(8.2)$ & $2,278(3.2)$ & 7.9 & $352(16.1)$ & $5,213(7.3)$ & 6.8 & $532(24.3)$ & $7,491(10.5)$ & 7.1 \\
\hline Massachusetts & $94(2.7)$ & $886(1.3)$ & 10.6 & $185(5.2)$ & 1,592 (2.3) & 11.6 & 545 (15.4) & $4,680(6.6)$ & 11.6 & $730(20.6)$ & $6,272(8.9)$ & 11.6 \\
\hline Michigan & $85(5.0)$ & $1,903(1.7)$ & 4.5 & $180(10.7)$ & $3,316(3.0)$ & 5.4 & 369 (21.9) & $8,090(7.3)$ & 4.6 & $549(32.6)$ & $11,406(10.2)$ & 4.8 \\
\hline Minnesota & $62(4.5)$ & $898(1.3)$ & 6.9 & $116(8.4)$ & $1,630(2.4)$ & 7.1 & 259 (18.8) & $4,481(6.5)$ & 5.8 & $375(27.2)$ & 6,111 & 6.1 \\
\hline Mississippi & $10(4.2)$ & $877(2.3)$ & 1.1 & $16(6.8)$ & $1,451(3.9)$ & 1.1 & $75(31.6)$ & $3,610(9.7)$ & 2.1 & $91(38.4)$ & $5,061(13.5)$ & 1.8 \\
\hline Missouri & $58(5.7)$ & $1,213(1.7)$ & 4.8 & 109 (10.7) & $2,131(2.9)$ & 5.1 & $236(23.3)$ & $5,571(7.6)$ & 4.2 & $345(34.0)$ & $7,702(10.5)$ & 4.5 \\
\hline Montana & $8(5.3)$ & $152(1.3)$ & 5.3 & $14(9.2)$ & $261(2.2)$ & 5.4 & $40(26.3)$ & $857(7.3)$ & 4.7 & $54(35.5)$ & $1,118(9.5)$ & 4.8 \\
\hline Nebraska & $22(6.0)$ & $348(1.3)$ & 6.3 & $40(10.8)$ & $677(2.6)$ & 5.9 & $101(27.4)$ & $1,879(7.3)$ & 5.4 & 141 (38.2) & 2,556 (9.9) & 5.5 \\
\hline Nevada & $22(3.8)$ & $606(1.7)$ & 3.6 & $49(8.6)$ & $1,052(2.9)$ & 4.7 & $136(23.7)$ & $2,781(7.8)$ & 4.9 & $185(32.3)$ & $3,833(10.7)$ & 4.8 \\
\hline New Hampshire & $6(2.0)$ & $148(1.2)$ & 4.1 & $12(3.9)$ & $266(2.2)$ & 4.5 & $56(18.3)$ & $744(6.1)$ & 7.5 & $68(22.2)$ & $1,010(8.3)$ & 6.7 \\
\hline New Jersey & $152(3.7)$ & $1,501(1.5)$ & 10.1 & $297(7.1)$ & $2,671(2.6)$ & 11.1 & $708(17.0)$ & $6,942(6.9)$ & 10.2 & $1,005(24.1)$ & $9,613(9.5)$ & 10.5 \\
\hline New Mexico & $21(13.6)$ & $377(1.6)$ & 5.6 & $29(18.8)$ & $653(2.7)$ & 4.4 & 29 (18.8) & $1,782(7.5)$ & 1.6 & $58(37.7)$ & $2,435(10.2)$ & 2.4 \\
\hline New York & $274(3.7)$ & $3,415(1.5)$ & 8.0 & 565 (7.6) & $5,938(2.6)$ & 9.5 & $1,220(16.4)$ & $14,669(6.4)$ & 8.3 & 1,785 (23.9) & $20,607(9.0)$ & 8.7 \\
\hline North Carolina & $110(5.8)$ & $2,338(1.9)$ & 4.7 & $217(11.5)$ & $3,851(3.2)$ & 5.6 & $379(20.1)$ & $8,740(7.3)$ & 4.3 & $596(31.6)$ & $12,591(10.5)$ & 4.7 \\
\hline North Dakota & $13(8.4)$ & $151(1.4)$ & 8.6 & $19(12.3)$ & $265(2.5)$ & 7.2 & $39(25.3)$ & $679(6.3)$ & 5.7 & $58(37.7)$ & $944(8.8)$ & 6.1 \\
\hline Ohio & $72(4.0)$ & $2,449(1.8)$ & 2.9 & $143(7.9)$ & 4,098 (3.0) & 3.5 & 380 (20.9) & $10,070(7.4)$ & 3.8 & $523(28.7)$ & $14,168(10.4)$ & 3.7 \\
\hline Oklahoma & $20(5.1)$ & $870(1.7)$ & 2.3 & $42(10.8)$ & $1,489(3.0)$ & 2.8 & $83(21.3)$ & $4,103(8.2)$ & 2.0 & $125(32.1)$ & 5,592 (11.1) & 2.2 \\
\hline Oregon & $26(3.4)$ & $511(1.2)$ & 5.1 & $62(8.2)$ & $940(2.2)$ & 6.6 & $175(23.1)$ & $2,700(6.2)$ & 6.5 & $237(31.3)$ & $3,640(8.3)$ & 6.5 \\
\hline Pennsylvania & $97(3.8)$ & $2,299(1.7)$ & 4.2 & $207(8.0)$ & $3,912(2.8)$ & 5.3 & $443(17.1)$ & $9,057(6.6)$ & 4.9 & $650(25.1)$ & 12,969 (9.4) & 5.0 \\
\hline Puerto Rico & $-\pi(-)$ & $421(1.7)$ & 1.0 & $9(10.3)$ & $750(3.1)$ & 1.2 & $28(32.2)$ & $2,033(8.4)$ & 1.4 & $37(42.5)$ & $2,783(11.4)$ & 1.3 \\
\hline Rhode Island & $16(5.4)$ & $175(1.6)$ & 9.1 & $22(7.5)$ & $288(2.7)$ & 7.6 & $44(14.9)$ & $594(5.6)$ & 7.4 & 66 (22.4) & $882(8.3)$ & 7.5 \\
\hline South Carolina & $31(4.7)$ & $1,093(1.9)$ & 2.8 & $63(9.6)$ & $1,897(3.3)$ & 3.3 & 154 (23.4) & 4,499 (7.9) & 3.4 & $217(33.0)$ & $6,396(11.2)$ & 3.4 \\
\hline South Dakota & $5(4.3)$ & $168(1.4)$ & 3.0 & $14(12.2)$ & $280(2.3)$ & 5.0 & $17(14.8)$ & $845(7.0)$ & 2.0 & $31(27.0)$ & $1,125(9.3)$ & 2.8 \\
\hline Tennessee & $27(3.6)$ & $1,325(1.6)$ & 2.0 & $56(7.5)$ & 2,383 (2.9) & 2.3 & 178 (23.7) & $6,579(8.1)$ & 2.7 & $234(31.2)$ & $8,962(11.1)$ & 2.6 \\
\hline Texas & $403(6.6)$ & $6,395(1.7)$ & 6.3 & $728(11.9)$ & $11,138(2.9)$ & 6.5 & $1,447(23.7)$ & 29,265 (7.7) & 4.9 & 2,175 (35.6) & $40,403(10.6)$ & 5.4 \\
\hline Utah & $62(6.2)$ & $643(1.3)$ & 9.6 & $112(11.2)$ & $1,117(2.3)$ & 10.0 & $252(25.1)$ & $3,471(7.1)$ & 7.3 & $364(36.3)$ & 4,588 (9.4) & 7.9 \\
\hline Vermont & $-(-)$ & $70(1.2)$ & 5.7 & $7(5.3)$ & $111(2.0)$ & 6.3 & $18(13.6)$ & $314(5.6)$ & 5.7 & $25(18.9)$ & $425(7.5)$ & 5.9 \\
\hline Virginia & $96(4.5)$ & $1,660(1.7)$ & 5.8 & $168(7.9)$ & $2,762(2.8)$ & 6.1 & 356 (16.7) & $6,820(6.8)$ & 5.2 & $524(24.6)$ & $9,582(9.5)$ & 5.5 \\
\hline Washington & $36(2.3)$ & $982(1.1)$ & 3.7 & $100(6.3)$ & $1,878(2.1)$ & 5.3 & $242(15.2)$ & $5,456(6.2)$ & 4.4 & $342(21.5)$ & 7,334 (8.4) & 4.7 \\
\hline West Virginia & $-(-)$ & $343(1.8)$ & 0.9 & $16(11.4)$ & $573(3.1)$ & 2.8 & $35(25.0)$ & 1,664 (8.9) & 2.1 & $51(36.4)$ & $2,237(12.0)$ & 2.3 \\
\hline Wisconsin & $49(5.2)$ & $938(1.4)$ & 5.2 & $104(11.0)$ & 1,699 (2.6) & 6.1 & $179(19.0)$ & $4,561(7.0)$ & 3.9 & $283(30.0)$ & 6,260 (9.6) & 4.5 \\
\hline Wyoming & $8(10.5)$ & $81(1.2)$ & 9.9 & $10(13.2)$ & $144(2.1)$ & 6.9 & $9(11.8)$ & $472(6.8)$ & 1.9 & $19(25.0)$ & $616(8.9)$ & 3.1 \\
\hline Total & $3,282(4.5)$ & $61,810(1.6)$ & 5.3 & 6,393 (8.7) & $107,167(2.8)$ & 6.0 & $14,119(19.2)$ & $278,342(7.2)$ & 5.1 & $20,512(27.8)$ & $385,509(9.9)$ & 5.3 \\
\hline
\end{tabular}

Abbreviations: ART = assisted reproductive technology; PTB = preterm birth; $\mathrm{VPTB}=$ very preterm birth .

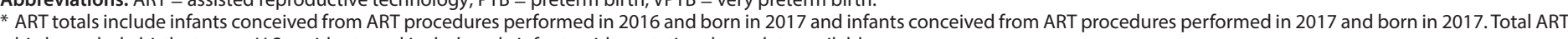
births exclude births to non-U.S. residents and include only infants with gestational age data available.

+ In cases of missing residency data (0.3\%), the patient's residence was assigned as the location where the ART procedure was performed.

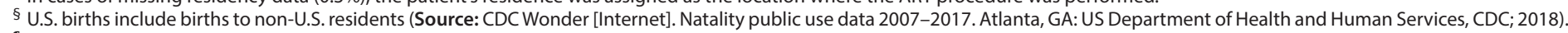

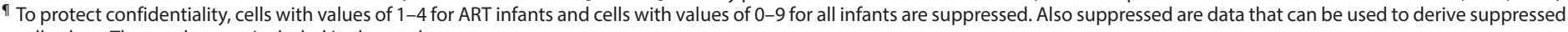
cell values. These values are included in the totals. 
TABLE 7. Percentage of low birthweight $(<2,500 \mathrm{~g})$, preterm $(<37$ weeks), and small for gestational age infants among singleton infants born with assisted reproductive technology* and all U.S. infants, by female patient's reporting area of residence ${ }^{\dagger}$ at time of treatment - United States and Puerto Rico, 2017

\begin{tabular}{|c|c|c|c|c|c|c|}
\hline \multirow[b]{2}{*}{ Patient's reporting area of residence } & \multicolumn{2}{|c|}{$\begin{array}{c}\text { Low birthweight } \\
(<2,500 \mathrm{~g})\end{array}$} & \multicolumn{2}{|c|}{$\begin{array}{c}\text { Preterm } \\
(<37 \text { wks })\end{array}$} & \multicolumn{2}{|c|}{$\begin{array}{l}\text { Small for gestational age } \\
(22-44 \mathrm{wks})\end{array}$} \\
\hline & ART infants (\%) & All infants (\%) & ART infants (\%) & All infants (\%) & ART infants (\%) & All infants (\%) \\
\hline Alabama & 11.6 & 8.1 & 23.0 & 9.9 & 8.8 & 11.4 \\
\hline Alaska & 9.8 & 4.8 & 11.5 & 7.4 & 10.0 & 6.5 \\
\hline Arizona & 8.0 & 6.0 & 14.5 & 7.6 & 7.0 & 9.1 \\
\hline Arkansas & 8.8 & 7.5 & 17.3 & 9.5 & 6.8 & 10.7 \\
\hline California & 7.5 & 5.4 & 12.3 & 7.1 & 8.2 & 9.3 \\
\hline Colorado & 9.1 & 7.3 & 16.1 & 7.1 & 10.4 & 13.0 \\
\hline Connecticut & 7.8 & 6.1 & 13.2 & 7.5 & 7.1 & 9.7 \\
\hline Delaware & 9.7 & 7.2 & 16.5 & 8.3 & 8.8 & 10.2 \\
\hline District of Columbia & 6.8 & 8.5 & 9.1 & 8.7 & 8.2 & 12.5 \\
\hline Florida & 8.7 & 7.2 & 14.9 & 8.5 & 8.2 & 10.7 \\
\hline Georgia & 7.4 & 8.0 & 15.6 & 9.4 & 5.9 & 11.9 \\
\hline Hawaii & 8.2 & 6.8 & 14.3 & 8.7 & 9.4 & 10.8 \\
\hline Idaho & 9.9 & 5.3 & 15.2 & 6.9 & 6.3 & 8.6 \\
\hline Illinois & 8.2 & 6.6 & 13.5 & 8.4 & 7.7 & 9.6 \\
\hline Indiana & 7.5 & 6.6 & 13.4 & 8.0 & 5.5 & 9.5 \\
\hline lowa & 8.0 & 5.1 & 14.3 & 7.4 & 6.6 & 7.2 \\
\hline Kansas & 5.5 & 5.7 & 13.5 & 7.8 & 4.2 & 8.2 \\
\hline Kentucky & 6.9 & 7.0 & 13.7 & 9.2 & 5.2 & 9.9 \\
\hline Louisiana & 10.4 & 8.7 & 19.5 & 10.6 & 6.9 & 11.2 \\
\hline Maine & 8.2 & 5.7 & 12.5 & 7.2 & 7.0 & 8.7 \\
\hline Maryland & 9.2 & 7.1 & 15.3 & 8.6 & 7.5 & 9.9 \\
\hline Massachusetts & 7.3 & 5.7 & 12.3 & 7.0 & 7.9 & 9.4 \\
\hline Michigan & 7.8 & 6.9 & 14.4 & 8.2 & 5.8 & 10.0 \\
\hline Minnesota & 7.4 & 5.2 & 14.3 & 7.1 & 6.7 & 7.8 \\
\hline Mississippi & 6.1 & 9.6 & 20.2 & 11.4 & 5.5 & 13.0 \\
\hline Missouri & 8.1 & 6.9 & 14.7 & 8.5 & 6.3 & 9.4 \\
\hline Montana & 8.3 & 6.3 & 20.8 & 7.8 & 6.3 & 9.7 \\
\hline Nebraska & 5.8 & 5.6 & 18.4 & 7.8 & 2.5 & 7.7 \\
\hline Nevada & 7.6 & 7.5 & 16.8 & 8.9 & 7.7 & 11.4 \\
\hline New Hampshire & 7.3 & 5.3 & 12.1 & 6.6 & 10.2 & 8.5 \\
\hline New Jersey & 8.5 & 6.1 & 14.7 & 7.6 & 8.1 & 9.9 \\
\hline New Mexico & 19.6 & 8.0 & 17.2 & 8.8 & 16.0 & 12.7 \\
\hline New York & 8.1 & 6.3 & 12.7 & 7.2 & 8.6 & 10.4 \\
\hline North Carolina & 7.8 & 7.6 & 14.1 & 8.6 & 7.6 & 10.9 \\
\hline North Dakota & - & 4.9 & 14.3 & 6.9 & 6.0 & 7.5 \\
\hline Ohio & 7.6 & 6.9 & 12.7 & 8.5 & 7.0 & 9.9 \\
\hline Oklahoma & 7.8 & 6.6 & 13.1 & 9.4 & 5.3 & 8.9 \\
\hline Oregon & 7.9 & 5.2 & 14.6 & 6.7 & 5.9 & 8.1 \\
\hline Pennsylvania & 8.0 & 6.7 & 13.3 & 7.6 & 6.6 & 10.0 \\
\hline Puerto Rico & - & 9.3 & 14.9 & 10.3 & - & 14.5 \\
\hline Rhode Island & 6.8 & 5.7 & 10.2 & 6.5 & 7.7 & 9.3 \\
\hline South Carolina & 7.4 & 7.8 & 16.2 & 9.2 & 5.6 & 10.7 \\
\hline South Dakota & - & 5.0 & 8.2 & 7.3 & - & 7.3 \\
\hline Tennessee & 8.0 & 7.5 & 19.8 & 9.3 & 7.3 & 10.4 \\
\hline Texas & 9.4 & 6.7 & 17.3 & 8.8 & 7.2 & 9.9 \\
\hline Utah & 9.7 & 5.4 & 17.2 & 7.5 & 8.2 & 8.8 \\
\hline Vermont & 6.5 & 5.1 & 11.7 & 6.0 & 7.5 & 9.1 \\
\hline Virginia & 8.1 & 6.6 & 13.1 & 7.7 & 7.8 & 10.1 \\
\hline Washington & 7.5 & 5.2 & 10.8 & 6.8 & 7.8 & 8.2 \\
\hline West Virginia & 11.1 & 7.7 & 23.7 & 10.1 & - & 10.5 \\
\hline Wisconsin & 5.9 & 6.0 & 13.4 & 7.8 & 4.8 & 8.5 \\
\hline Wyoming & - & 7.3 & 7.8 & - & - & 12.4 \\
\hline Total & 8.1 & 6.6 & 14.0 & 8.1 & 7.6 & 9.9 \\
\hline
\end{tabular}

Abbreviation: ART = assisted reproductive technology.

* ART totals include infants conceived from ART procedures performed in 2016 and born in 2017 and infants conceived from ART procedures performed in 2017 and born in 2017. Total ART births exclude births to non- U.S. residents and include only infants with gestational age data available.

$\dagger$ In cases of missing residency data $(0.3 \%)$, the patient's residence was assigned as the location where the ART procedure was performed.

$\S$ U.S. births include births to non-U.S. residents (Source: CDC Wonder [Internet]. Natality public use data 2007-2017. Atlanta, GA: US Department of Health and Human Services, CDC; 2018).

9 To protect confidentiality, cells with values of 1-4 for ART infants and cells with values of 0-9 for all infants are suppressed. Also suppressed are data that can be used to derive suppressed cell values. These values are included in the totals. 

The Morbidity and Mortality Weekly Report (MMWR) Series is prepared by the Centers for Disease Control and Prevention (CDC) and is available free of charge in electronic format. To receive an electronic copy each week, visit MMWR at https://www.cdc.gov/mmwr/index.html.

Readers who have difficulty accessing this PDF file may access the HTML file at https://www.cdc.gov/mmwr/volumes/69/ss/ss6909a1.htm?s_cid=ss6909a1_w. Address all inquiries about the MMWR Series, including material to be considered for publication, to Executive Editor, MMWR Series, Mailstop E-90, CDC, 1600 Clifton Rd., N.E., Atlanta, GA 30329-4027 or to mmwrq@cdc.gov.

All material in the MMWR Series is in the public domain and may be used and reprinted without permission; citation as to source, however, is appreciated. MMWR and Morbidity and Mortality Weekly Report are service marks of the U.S. Department of Health and Human Services.

Use of trade names and commercial sources is for identification only and does not imply endorsement by the U.S. Department of Health and Human Services.

References to non-CDC sites on the Internet are provided as a service to $M M W R$ readers and do not constitute or imply endorsement of these organizations or their programs by CDC or the U.S. Department of Health and Human Services. CDC is not responsible for the content of these sites. URL addresses listed in $M M W R$ were current as of the date of publication.

ISSN: $1546-0738$ (Print) 